Proceedings of the Prehistoric Society 85, 2019, pp. 131-159 ( The Prehistoric Society 2019. This is an Open Access article, distributed under the terms of the Creative Commons Attribution licence (http:// creativecommons.org/licenses/by/4.0/), which permits unrestricted reuse, distribution, and reproduction in any medium, provided the original work is properly cited.

doi:10.1017/ppr.2019.6 First published online 15 August 2019

\title{
Mesolithic Fireplaces and the Enculturation of Early Holocene Landscapes in Britain, with a Case Study from Western Scotland
}

\author{
By STEVEN MITHEN ${ }^{1}$
}

In light of the enculturation of landscapes by ethnographically documented hunter-gatherers, we should expect Mesolithic hunter-gatherers to have endowed their early Holocene landscapes with meaning. Attempts to find evidence for this have focussed on the unusual and exotic-those aspects of the archaeological record that seem immediately unrelated to subsistence. In this contribution, I suggest that fireplaces, ubiquitous on Mesolithic sites and often swiftly passed over in site reports as evidence for cooking alone, had played a key role in the process of landscape enculturation. Although we cannot reconstruct the specific meanings once attached to early Holocene landscapes, by appreciating the social and cultural significance of fireplaces we gain a more holistic view of the Mesolithic than is currently the case, whether in those studies that focus on settlement and subsistence or those that cite examples of ritual. In the course of making this argument, I summarise the evidence for fireplaces from Mesolithic Britain, noting the need for more systematic reporting. Finally, I provide a case study from western Scotland that seeks to view a suite of fireplaces in the context of the landscape topography, early Holocene environments, subsistence economy, and by drawing on selected ethnographic analogies.

Keywords: Mesolithic, Fireplaces, Landscape, Enculturation

Amongst ethnographically documented hunter-gatherers, landscapes are enculturated: they have meanings conferred upon them. The meanings derive from a mix of personal experience, social history, tradition, ritual, and cosmology. They are constantly reproduced and revised and influence the whole breadth of activities undertaken in the landscape. We should assume the same for the early Holocene landscapes of Mesolithic Britain (Zvelebil 2003) - a view with which I am confident all archaeologists would concur. As with studies of the Blackfoot Indians of the North-western Plains of the USA, and to paraphrase Oetelaar (2016, 42), while archaeologists may predominately interpret Mesolithic archaeology as representing subsistence and settlement strategies adapted to the early Holocene environments, the Mesolithic people themselves are likely to have also

${ }^{1}$ Department of Archaeology, University of Reading, Whiteknights House, Whiteknights, Reading, RG6 6AH. Email: s.j.mithen@reading.ac.uk been addressing historical, social, and cosmological imperatives. This is widely acknowledged: Mesolithic, and hopefully Neolithic, archaeology is long past the time when Bradley $(1984,11)$ thought it appropriate, or at least entertaining, to claim that Mesolithic people were considered to only have ecological relationships with hazelnuts - a claim that was inaccurate at the time (as Bradley was well aware).

The meanings once conferred on the early Holocene landscapes are entirely lost to us: we can neither reconstruct Mesolithic cosmology nor attain the chronological resolution required for reconstructing social history. Nevertheless, we cannot ignore the strong likelihood that early Holocene landscapes were enculturated and replete with meaning for Mesolithic people. How might this have influenced the archaeological record? What archaeological evidence might provide an insight into the nature and/or process of landscape enculturation? 
While the tendency has been to look for the unusual and exotic, such as evidence for ritual deposition, the most significant evidence might be both ubiquitous and seemingly mundane: fireplaces. I use 'fireplace' as a generic term to encompass archaeological features described as hearths, areas of burning, ovens, fire-pits, and so forth. Fireplaces in Mesolithic Britain are predominately interpreted as evidence for cooking, potentially involving a variety of methods such as steaming, baking, and roasting on hot stones (Milner 2009), as is the case for those from elsewhere in Europe (eg, the Netherlands, Peters \& Niekus 2017; Finland, Sikk 2016). Cooking was certainly an important function of fireplaces, and needs further investigation, along with the use of fireplaces for preparing resins, heating flint, and supporting other functional tasks whether by the heat or light they provide (Warren 2005). In this contribution, however, I will focus on the social role of the fireplace within Mesolithic communities.

\section{ENCULTURED LANDSCAPES}

The landscapes of ethnographically documented huntergatherers have multiple layers of meanings intricately bound together. Archaeologists concerned with the Mesolithic and Neolithic are acutely aware of such enculturation and have often cited ethnographic examples potentially relevant to these periods. Tilley (1994), for example, describes the enculturation of landscapes by Australian aborigines, the Mistassini Cree and Koyukon of North America, and cultivators from Melanesia and the American South-west, before reflecting on the Mesolithic and Neolithic of Pembrokeshire, the Black Mountains, and Cranborne Chase. Bradley (2000) framed his discussion of the archaeology of natural places and Neolithic archaeology in Britain by a focus on Saami hunters and reindeer herders, while Zvelebil (2003) looked towards the Kets of western Siberia, and the Nukak of Amazonia. The edited volumes by Jordan (2010) and Lovis \& Whallon (2016) contain numerous ethnographic studies of potential value to Mesolithic archaeologists concerned with the enculturation of landscape. The challenge such studies provide, however, is the remarkable diversity of beliefs held by hunter-gatherers about their landscapes, many of which provide vivid demonstrations of human cognitive fluidity (Mithen 1996) as the domains of nature, society, and material culture blend together in quite remarkable ways.

No single ethnographic analogy will ever be sufficient for Mesolithic Britain consisting of more than 5000 years of hunter-gatherers living in diverse environmental settings between the end of the Pleistocene (c. 11,650 BP) and arrival of the Neolithic (c. 6000 BP). We might however, draw some generalisations from the ethnographic record to guide our archaeological studies. One common theme is that supernatural beings created distinctive features of the landscape and continue to have agency in the world (eg, for the Walpiri of Australia, Meggitt 1986; the Blackfoot Indians of North America, Oetelaar 2016; and the Khanty of Siberia, Jordan 2003). Human experience, memory, and oral history often provide further layers of meaning, with features of the landscape becoming associated with memories of recent events (such as the trees of the Central Kalahari for the San, Takada 2016). Landscapes can be deliberately and permanently marked, such as by pictographs or cairns, or temporally modified by alignments of stones and branches to alert others to specific events; they can be unintentionally altered by the creation of tracks via the repeated use of routeways (Lovis \& Whallon 2016). The naming of places is pervasive and can be paramount (Basso 1996; Jordan 2003). Names can relate to any type of meaning: cosmological, ritual, spiritual, historic events in memory, landscape characteristics, and resource availability.

While living and acting within an enculturated environment, hunter-gatherers also adapt to resource distributions: the ecological structure of the environment provides a further level of meaning, one inextricably linked with social history and cosmology. In this regard, Davies et al. (2005) should reconsider their suggestion that ecological and cultural interpretations of Mesolithic activity are opposed because this fails to appreciate the true complexity of the human mind that can accommodate views seemingly contradictory to a modern western perspective (Mithen 1996). Moreover, mythological stories and ritual activities may contain critical information about managing infrequent crashes in specific foods (Minc 1986). The recounting of journeys, real or imaginary, and of named places within stories and ceremonies submits 'anchor points' to memory, essential for maintaining social networks in what Lovis (2016) describes as 'big rough spaces with few people'. Story-telling among the Agta hunter-gatherers coordinates group behaviour and facilitates cooperation, this being consistent with studies of other hunter-gatherers (Smith et al. 2017).

As hunter-gatherers move across their landscapes, different types of meaning rise to the fore as parti- 


\section{S. Mithen. MESOLITHIC FIREPLACES \& ENCULTURATION, EARLY HOLOCENE, BRITAIN}

cular topographic features, views, or human-made marks (such as a past campsite or a pictograph) are encountered. Such meanings might be cosmological, historical, ecological, or from personal memory, and are then replaced by others as the viewpoint changes (Lovis \& Whallon 2016). The flow of perceptions and meanings will vary between individuals, reflecting their age, experience, and interests. The different concerns of men and women can lead to 'gendered landscapes' (eg, Funk 2011), while people may have differential access to sacred knowledge about the landscape (Whallon \& Lovis 2016).

The manner in which enculturation starts is of particular interest to those archaeologists who study human dispersals into previously unoccupied landscapes (Rockman \& Steele 2003). The Kesyehot'ine group of the Chipewyan hunter-fishers undertook this in three stages when they moved southwards from the central Canadian subarctic into the boreal forest in the late 18th century (Jarvenpa \& Brumback 2016). They initially learned to use prominent natural features as travel corridors and wayfinding guides, gradually giving them names and thereby endowing them with cultural significance. A second stage involved marking the landscape with their own trails, animal traps, and structures. Some of these had spiritual dimensions. The iuse, for instance, was a trap for catching lynx using a baited stake within a horseshoe enclosure. The placing of the stake was a ritual act, with the iuse carrying a complex symbolic message about livelihood, cosmological power, and inter-dependency between humans and animals. A third stage of landscape enculturation involved the emergence of a mortuary-based pilgrimage complex. Within eight generations, c. 200 years, the Kesyehot'ine had 'moved into a different area and through lived experience made it their own' (Jarvenpa \& Brumback 2016, 18).

\section{THE MESOLITHIC}

Mesolithic archaeologists appreciate that early Holocene hunter-gatherers created and lived within encultured landscapes, even if they do not always make this explicit. Cummings $(2000,93)$ suggests that Mesolithic sites in Pembrokeshire 'were meaningfully situated for a variety of reasons relating to the myths, metaphors and memories that were associated with the lived-in and active landscape'. When writing about the Mesolithic in Scotland, Warren (2005, 117) describes landscapes as being 'redolent with meaning being generated by the activities of spirits, animals and other agencies', while Lillie (2015) seeks to provide a 'social narrative' for Mesolithic lifeways in Wales. Davies et al. (2005), drawing analogy with the Koyukon of Alaska and Ixtepejano of Mexico, suggest Mesolithic hunter-gatherers might have viewed areas of their landscape with fear and made paths and clearings to avoid malevolent forces. More generally, there has been an emphasis on social accounts in which 'landscapes were created and reproduced through the habitual, routine practices of people's lives' and how 'interactions with plants, animals and the landscape more generally are structured by cultural rules' (Taylor 2018, 494, citing Conneller 2004; 2005; Edmonds 1997; McFadyen 2006).

These are all compelling ideas - but finding supporting evidence is challenging. Attempts to do so have drawn on the unusual types of evidence from the Mesolithic, those for which adaptationist interpretations appear insufficient. The shell middens on Oronsay are unusual because of their number, size, and the presence of human remains (Mellars 1987). Both Pollard (2000) and Cummings (2003) have drawn on these features to invoke the presence of ancestors and social gatherings. The unique combination of numerous beads, a figurine, and prominent topography at Nab Head in Wales (David 2007) led Tilley $(1994,84)$ to claim these provide 'a tantalizing glimpse of the symbolic dimensions of social being-inthe-landscape during the Mesolithic'. The unusual evidence at Star Carr - worked antler frontlets, accumulations of harpoons and stone tools suggesting deliberate deposition - has been subject to a multitude of interpretations that refer to various types of encultured landscapes and the process of enculturation (eg, Conneller 2004; 2005; Taylor et al. 2018). Chatterton (2006, 104), for instance, suggests the deposition of red antler harpoons into the shallow water of the lake edge 'may have involved actions which were designed to offer respect to animals killed, either through a taboo against reuse or in the regeneration and maintenance of the animal kingdom from which the slain animals came'. While arguments based on the 'unusual' can be persuasive, the dilemma they present is that the social and symbolic is detached from the everyday life of the Mesolithic as represented by the vast majority of its archaeological evidence.

Warren (2005), Spikins et al. (2010), and MacInnes (2016) have indicated a way forward by drawing attention to the social significance of fireplaces. 
Warren refers to fire as a symbolic referent and how the 'social world would have revolved around small pockets of light' (Warren 2005, 127), while Spikins et al. $(2010,189)$ drew on ethnographic analogy to explain the 'embedded nature of fire within daily social and spiritual life' in the Mesolithic. MacInness describes fire as a socialising instrument, suggesting it can enhance the creation of memories. She writes how 'fire may have been seen to hold life-sustaining properties embodied in warmth and light, bringing forth sociality and acting to (re)make the group through its role in everyday practices that reaffirmed these shared understandings' (MacInnes 2016, 51-2).

\section{FIREPLACES, NIGHT-TIME TALK, AND ENCULTURING THE LANDSCAPE}

Following the lead of Warren, Spikins et al., and MacInness, we should consolidate their views and draw further insights from the ethnographic record regarding the social use of fire. The following examples are illustrative regarding four key roles played by fire in social relations with particular regard to landscape enculturation.

Fire provides warmth, light, and creates the emotional and physiological states that are especially receptive to new ideas and information This is illustrated by Wiessner's (2014) study of firelight talk among the Ju/'hoansi Bushmen, from which she generalises to all hunter-gatherers. Following meticulous recording and analysis of conversations, Wiessner identified day-time talk to be about economic matters and social relations. When seated around the fire at night, however, the $\mathrm{Ju} /$ 'hoansi told enthralling stories and tales about people in the recent and distant past, and engaged in singing, dancing, and talk of the supernatural. Wiessner explained why there is such difference:

'Sufficiently bright firelight represses the production of melatonin and energizes at a time when little economically productive work can be done; time is ample. In hot seasons, the cool of the evening releases pent up energy; in cold seasons, people huddle together. Fireside gatherings are often, although not always, composed of people of mixed sexes and ages. The moon and starlit skies awaken imagination of the supernatural, as well as a sense of vulnerability to malevolent spirits, predators, and antagonists countered by security in numbers. Body language is dimmed by firelight and awareness of self and others is reduced. Facial expressions-flickering with the flames-are either softened, or in the case of fear or anguish, accentuated. Agendas of the day are dropped while small children fall asleep in the laps of kin. Whereas time structures interactions by day because of economic exigencies, by night social interactions structure time and often continue until relationships are right. Foragers make use of day-time efficiently and night-time effectively'. (Wiessner 2014, 1402)

Not restricting herself to the Ju/'hoansi Bushmen, Wiessner reviewed evidence from hunter-gatherers around the world. She found striking commonalities with regard to night-time activities, to conclude that:

'When the night appears to have really mattered was for the extension of cultural institutions over time and space to link individuals from different bands into larger "imagined communities" beyond village limits, an enterprise that involved complex cognition and time-consuming information transfer. In most hunter-gatherer societies, firelit hours drew aggregations of individuals who were out foraging by day and provided time for ventures into such virtual communities, whether human or supernatural, via stories and ritual. Stories conveyed unifying cosmologies and charters for rules and rites governing behavior. These stories also conveyed information about the nature of individuals in the present and recent past, their experiences and feelings, as well as factual knowledge about long-distance networks, kinship, and land tenure. Stories told by firelight put listeners on the same emotional wavelength, elicited understanding, trust, and sympathy, and built positive reputations for qualities like humor, congeniality, and innovation'. (Wiessner 2014, 1403)

Experimental studies provide a physiological basis to these ethnographic observations. These have demonstrated that sitting by fires induces relaxation as part of a multisensory, absorptive and social experience' (Lynn 2014, 983). As such, the warmth, light, and aromas of the fire would have created emotional 


\section{S. Mithen. MESOLITHIC FIREPLACES \& ENCULTURATION, EARLY HOLOCENE, BRITAIN}

and physiological states that were especially receptive to new ideas and information.

\section{Fire provides a means to engage with the spirit world}

The hunters and herders of northern taiga landscapes intuitively appear to provide better analogies for the British Mesolithic than the Ju/'hoansi Bushmen. The fireplace has a central role in the process by which the Evenki of Siberia turn tracts of forest into cultural landscapes imbued with ancestral and spiritual meanings. Lavrillier (2010, 221), writes that:

'The hearth, located at the centre of the dwelling, surrounded by logs or stones, or occasionally marked by the presence of a larger schist slab, is considered to be a vector of communication linking the world of living people with the lower world domain of the dead, and with the 'souls to be born' who are in the upper world'.

Between spring and autumn a second fire is kept burning outside the tent, which serves the same purpose.

The Selk'nam of Tierra del Fuego have also been proposed as an effective analogy for Mesolithic Britain (Manzi \& Spikins 2008; Spikins et al. 2010). For these hunter-gatherers fire was connected to the spirit world, and was especially important in male initiation ceremonies. Spirits such as Ksohort emerged from the fire and rituals took place with the light of a huge bonfire. Fire enabled people to move between the living and the spirit worlds (Manzi \& Spikins 2008).

Amongst the !Kung of Nyae Nyae, special fireplaces are constructed for ritual activities, such as within the centre of a dance circle. Marshall $(1976,91)$ describes the following rites as requiring special fires: the Menarcheal Rite, the Rite of the First Kill (performed when a boy kills his first large game animal), another hunting rite, a rite for a novice medicine man, n/um/ k"xau ('owner of medicine), and the rite of a child's first haircut.

\section{Fire and smoke have transformative properties}

It is the nature of fire to transform material, by cooking foodstuffs to make then edible, by heating flint to change its knapping properties, to melt wax when making resins. Fire and smoke can also transform the non-material properties of objects and living things. The Siberian Iukagir hunters consider the fire contained in small metal stoves to be most important part of the interiors of their cabins, cabins having replaced tents in the 1960s (Willerslev 2010). The fire transforms animal flesh from the game they hunt into a foodstuff by de-subjectifying what had, up until then, been a person. Their story-telling around the stove is particular interesting because of its minimalist character: 'the stories are short, uneven and often incomplete ... one has to guess the meaning according to the general context of the story or according to previous sentences, or by deciphering the bodily gestures of the speaker' (Willersley 2010, 63). Amongst the Chukchis reindeer herders, the hearth, its charcoal, and smoke, protect family members, perpetuate the reindeer herd, and enable the temporary appropriation of the piece of landscape in which the people were currently dwelling (Vaté 2010). The smoke maintains the virility of the reindeer. This can only be guaranteed, however, by smoke from particular types of wood and so the hearths are regular cleaned out to avoid burning material that might have the opposite effect.

\section{The fireplace is a means to reproduce and reaffirm social relationships and values}

For the Selk'nam, the making of a fireplace took precedence over the construction of a shelter when at a new camping place (Spikins et al. 2010, 186). The practical tasks that made use of fire, such as keeping warm, cooking food, and preparing tools, merged seamlessly with the social and symbolic uses for fire and the fireplace. Although Selk'nam fireplaces were often no more than a slightly shallow pit or even flat on the ground, they symbolised social cooperation, the fire providing a constant social, metaphorical, and ideological presence in Selk'nam life (Spikins et al. 2010, 186).

The Kung of Nyae Nyae also prioritised making fire over building shelters at a new encampment (Marshall 1976, 79). For them:

'The clearest visible indication of a family's location is the fire. Always, summer and winter, every nuclear family has its fire, which is kept burning all night. The fire is the nuclear family's home, its gathering place, its rightful place to be. In a way, a fire is more of an unchanging home than is a house or a plot of ground from which a family might depart ... fires are constant - the shelters are whims' (Marshall 1976, 84-6) 
The !Kung construct and reproduce their social relationships via the spatial arrangement of their fireplaces and of people around them. The fires of nuclear families that compose an extended family are always positioned near to each other rather than being dispersed amongst those of other families in the encampment. From the age of 8 or 9 , boys and girls sleep at fires apart from those of their parents. Several boys sleep together at a boys' fire; the girls will sleep either with a widowed grandmother or some other widow. At the family fire, men will sit on one side and women on the other (Marshall 1976).

\section{Summary}

Drawing on such ethnographic studies, it is apparent that the activities around fireplaces - story-telling, singing, dancing, ritual, engaging with the supernatural, some of which are embedded within the otherwise practical tasks of cooking and tool making - played a key role in the on-going enculturation of huntergatherer landscapes. It was primarily during night-time, fire-lit exchanges that memories about past events and the social significance of places within the landscapes were reinforced and shared with others, that origin myths were retold, cultural rules were strengthened, and news about the natural world was shared.

There may have been no intent and no restriction in scale. Landscape enculturation may have been an intended outcome of large social gatherings that involved ceremony, ritual and special fires as large as the Tlingit fires that blazed 6-7 ft (c. 2.1-2.4 m) high over 4 days on the Pacific North-west coast as the elders recounted their stories (Wiessner 2014). Landscape enculturation would have also arisen from the informal chatter of a few people seated around glowing embers that might have been constructed to provide a little warmth and light.

\section{THE USE OF FIRE IN THE MESOLITHIC}

In light of the role of fire for cooking food and supporting a range of practical tasks, the widespread evidence of fire at Mesolithic sites is not surprising. Prior to considering the social role of fireplaces, we should note that fire was also used as a means of landscape management, as evident from microscopic charcoal within sediment cores associated with vegetation change. This provides a further type of landscape enculturation, especially when we note the potential symbolic role of trees (Moore 2003).
The idea of fire-management in the British Mesolithic was initially proposed by Mellars (1976) and then developed with further evidence by Edwards (1990), Zvelebil (1994), and Simmons (1996), among others. This has led to a useful debate about differentiating between naturally induced fires, such as from lightning strikes, and intentional firesetting (eg, Tipping 1996; 2008; Bishop et al. 2015). There are several persuasive examples of the deliberate use of fire in the British Mesolithic, such as its use for burning reed swamp at Star Carr (Mellars \& Dark 1998), maintaining pines within primary deciduous woodland in Ireland (Bradshaw et al. 1997), and managing hazel woodland at Loch an't Suidhe on the Isle of Mull (Edwards et al. 2007). Arguments that are more speculative include the use of fire for managing oaks and acorn production (Mason 2000).

Ethnographic studies of fire-stick farming by Australian Aborigines suggested diverse motivations including signalling, the regeneration of plant foods, flushing out prey, and extending habitable areas (Jones 2012). Drawing on ethnographic analogies from North and Central America, Davies et al. (2005) proposed a 'social aspect' of woodland clearance, suggesting its use to create buffer zones around settlements for protection from a woodland perceived as malevolent. While that particular argument might be countered by the widespread view amongst hunter-gatherers of a benevolent 'giving environment' (Bird-David 1990), it would not be surprising if accounts of burning events, along with naturally-induced fires, had entered the memories and stories of Mesolithic people and played a significant role in landscape enculturation. As Moore (2003, 141) proposed, the human interaction with trees was likely imbued with ritual and symbolism.

\section{MESOLITHIC FIREPLACES}

The majority of Mesolithic sites contain burnt artefacts, charred hazelnut shells, and, less frequently, burnt bone, indicating that fires had once been utilised. Exceptions are rare. The absence of burnt material within the extensive collections from Waun Fignen Fellen, south Wales, interpreted by Barton et al. (1995) as indicating a 'persistent place', is surprising, and might simply be a chance consequence of the location of excavation trenches. At many sites, burnt material is dispersed, with no evident concentrations. This might reflect an uncontrolled use of fire on- 


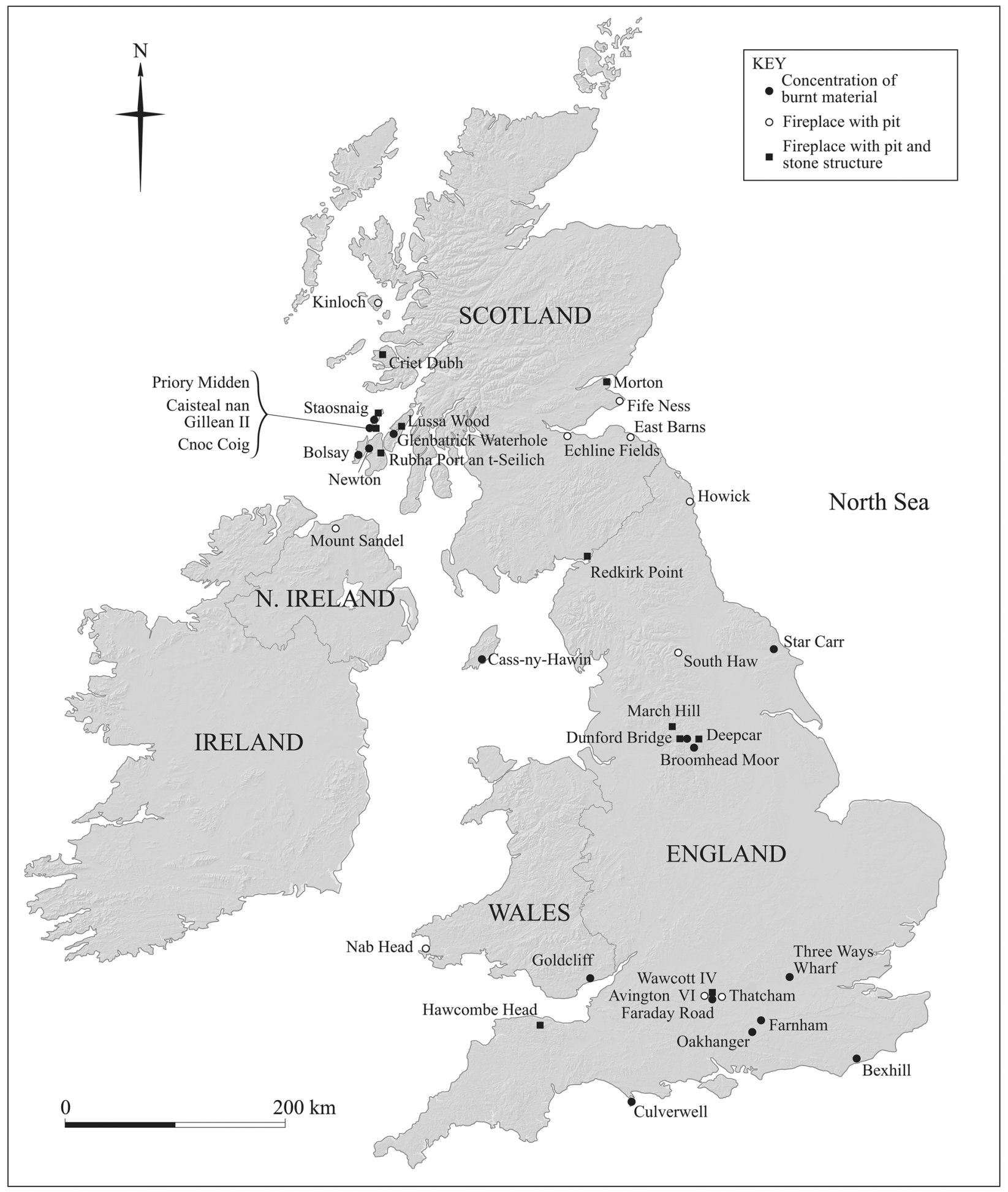

Fig. 1.

Map showing the distribution of fireplaces on a sample of Mesolithic sites in Britain (for descriptions see Table 1) 
TABLE 1: SUMMARY OF THE EVIDENCE FROM A SAMPLE OF MESOLITHIC SITES WHERE THE SPECIFIC LOCATION OF A HEARTH HAS BEEN PROPOSED (FOR LOCATION OF SITES SEE FIG. 1)

\begin{tabular}{|c|c|c|}
\hline Site & Evidence & References \\
\hline \multicolumn{3}{|c|}{ Concentrations of burnt material indicating the location of a fireplace } \\
\hline Caochanan Ruadha & $\begin{array}{l}\text { Concentration of burnt artefacts \& charcoal interpreted as a fire } \\
\text { setting }\end{array}$ & Warren et al. 2017 \\
\hline Caisteal nan Gillean II & $\begin{array}{l}3 \text { concentrations of heavily burnt } \& \text { fragmented shells, localised } \\
\text { close to the centre of the midden. These lack hearthstones but } \\
\text { have fire cracked rock nearby. Dispersed charcoal is present, this } \\
\text { most likely having been spread by trampling } \& \text { wind erosion }\end{array}$ & Mellars 1987 \\
\hline Priory Midden & $\begin{array}{l}\text { Burning throughout the sequence with } 2 \text { clearly defined hearths } \\
\text { in direct superposition \& closely associated with at least } 1 \text { tight } \\
\text { cluster of fire-cracked pebbles. A large fragment of burnt } \& \\
\text { worked whale bone was found immediately below the lower of } \\
\text { the two hearths }\end{array}$ & Mellars 1987 \\
\hline Cnoc Coig & $\begin{array}{l}\text { Clearly defined hearths in at least } 50 \text { locations, defined by well- } \\
\text { defined patches of heavily burned shells, usually roughly circular } \\
\text { in shape \& typically more compact than the surrounding } \\
\text { midden. Most were small, } 60-80 \mathrm{~cm} \text { in diameter, with a few up } \\
\text { to } 1.5 \mathrm{~m} \text {. Also, area of diffuse burnt material that appears to be } \\
\text { material cleaned out of hearths. Some hearths had stone settings, } \\
\text { as described in text. Many of the hearths have clear evidence for } \\
\text { several episodes of use marked by distinct horizons of burnt } \\
\text { shells, separated by } 1 \text { or more deposits of intervening unburnt } \\
\text { shell }\end{array}$ & Mellars 1987 \\
\hline Glenbatrick Waterhole & $\begin{array}{l}\text { Concentration of charcoal within a 'scooped pit' that cut } 10 \mathrm{~cm} \text {, } \\
\text { into underlying gravel. Interpreted as a cooking pit }\end{array}$ & Mercer 1974 \\
\hline Staosnaig & $\begin{array}{l}4.5 \mathrm{~m} \text { diameter circular pit, } 0.3-0.4 \mathrm{~m} \text { deep, containing a circular } \\
\text { cut } 1.8 \mathrm{~m} \text { diameter on its eastern edge (Feature F } 24 \text { ). It } \\
\text { contained large quantities of charred hazelnut shells } \& \text { other } \\
\text { plant material, burnt flint, \& bone fragments, but with limited } \\
\text { quantities of fire cracked rock } \& \text { wood charcoal. The burnt flint } \\
\text { was concentrated within the centre of the feature }\end{array}$ & Mithen \& Finlay 2000 \\
\hline Bolsay & $\begin{array}{l}\text { Multiple concentrations of burnt flint suggesting location of } \\
\text { hearths }\end{array}$ & Mithen et al. 2000a \\
\hline Newton & $\begin{array}{l}\text { Numerous discrete circular \& crescentic patches of scorched \& } \\
\text { slightly cemented gravel with a shallow depression filled with } \\
\text { midden material rich in charred hazelnut shell, flint artefacts, \& } \\
\text { burnt bone, interpreted as a sunken floor with numerous hearths }\end{array}$ & McCullagh 1989 \\
\hline Cass Ny Hawin & $\begin{array}{l}\text { A heart area is described within a } 3-4 \mathrm{~m} \text { hollow, presumably } \\
\text { identified by a concentration of burnt material although this is } \\
\text { not specified within the report. The hearth is interpreted to have } \\
\text { once been at the centre of a circular structure }\end{array}$ & Woodman 1987 \\
\hline Star Carr & $\begin{array}{l}\text { A discrete spread of carbonised wood that probably represents a } \\
\text { hearth in the wetland area, \& concentrations of burnt flint } \\
\text { amongst the lithic scatters. Charcoal indicates the hearths were } \\
\text { fuelled with birch \& willow/poplar }\end{array}$ & Milner et al. 2018 \\
\hline Dunford Bridge Site A & $\begin{array}{l}\text { Concentration of fire-cracked 'finds' which are interpreted as } \\
\text { 'undoubtedly' representing a hearth (the report does not specify } \\
\text { whether the finds are flints or other stone) }\end{array}$ & Radley et al. 1974 \\
\hline Goldcliff Trench J & $\begin{array}{l}\text { A cluster } \& \text { diffuse scatter of heat-fractured quartzite, most likely } \\
\text { heated to high temperatures } \& \text { then rapidly cooled in water }\end{array}$ & Bell 2007 \\
\hline
\end{tabular}


TABLE 1: (Continued)

\begin{tabular}{|c|c|c|}
\hline Site & Evidence & References \\
\hline Goldcliff Site B & $\begin{array}{l}\text { Calcined bone concentrated in } 1 \text { small area, } 1.5 \mathrm{~m} \text { diameter, } \\
\text { probably representing a hearth }\end{array}$ & Bell 2007 \\
\hline Goldcliff Site W & $\begin{array}{l}\text { Concentrations of charcoal \& burnt artefacts indicate the } \\
\text { position of hearths }\end{array}$ & Bell 2007 \\
\hline Broomhead Moor Site 5 & $\begin{array}{l}3 \text { hearths in the lowest part of the trench were confirmed by } \\
\text { charcoal \& burnt flint distributions. These were found in } \\
\text { association with } 5 \text { stake-holes \& artefact scatters }\end{array}$ & Radley et al. 1974 \\
\hline Faraday Road & $\begin{array}{l}\text { A small concentration of unworked burnt flint suggests at least } 1 \\
\text { hearth may have lain in the northern extent of the Mesolithic } \\
\text { layer }\end{array}$ & Ellis et al. 2003 \\
\hline Bex Hill & $\begin{array}{l}\text { Concentrations of burnt flint suggesting the former presence of a } \\
\text { hearth }\end{array}$ & Donnelly, pers. comm. \\
\hline Farnham & $\begin{array}{l}\text { Hearths defined by concentrations of 'crackled' flints \& charcoal } \\
\text { discoloration in the centres of } 2 \text { pits, interpreted as Mesolithic } \\
\text { structures. High frequencies of 'crackled' flints were found within } \\
\text { a third pit \& within a natural hollow into which Mesolithic } \\
\text { debris had been redeposited }\end{array}$ & Clark \& Rankine $1937-8$ \\
\hline Oakhanger & $\begin{array}{l}\text { Within Site V, } 5 \text { hearths were identified on the basis of clusters } \\
\text { of burnt flint \& fire-cracked stone. These were amidst an } \\
\text { extensive scatter of chipped } \\
\text { stone artefacts }\end{array}$ & Rankine 1952 \\
\hline Culverwell & $\begin{array}{l}4 \text { hearths indicated by well-defined areas of a very black } \\
\text { appearance } \& \text { areas of red well-fired clay } \& \text { containing large } \\
\text { quantities of burnt stone. An unusually large number of heavy } \\
\text { choppers/chopping tools, pounders, \& picks were found } \\
\text { concentrated round the hearths. The hearths were found in a } \\
\text { straight row adjacent to the eastern edge of what was interpreted } \\
\text { as a living floor. }\end{array}$ & Palmer 1999 \\
\hline Three Ways Wharf & $\begin{array}{l}2 \text { hearths identified by concentrations of burnt flint } \& \text { bone. } \\
\text { These are surrounded by the main concentrations of lithics, } \\
\text { interpreted as deriving from fireside activities }\end{array}$ & Lewis \& Rackham 2011 \\
\hline
\end{tabular}

Fireplaces within pits or depressions, and lacking evidence for a stone construction

\begin{tabular}{lll}
\hline East Barnes & $\begin{array}{l}\text { A charcoal-rich fill of an irregularly shaped pit near the centre of } \\
\text { the structure denotes a possible hearth }\end{array}$ & Gooder 2007 \\
\hline Fife Ness & $\begin{array}{l}\text { Concentrations of burnt flint within pits 10-28 cm deep \& 20- } \\
42 \mathrm{~cm} \text { wide that were within an arc of pits. The sides of the pits } \\
\text { did not show evidence of burning, \& so these might be deposited }\end{array}$ & $\begin{array}{l}\text { Wickham-Jones \& Dalland } \\
\text { flints taken from a fire elsewhere. A nearby patch of reddened } \\
\text { soil is the likely position of a hearth }\end{array}$ \\
\hline Echline Field & $\begin{array}{l}\text { A number of small \& shallow cut features in the centre of a circular } \\
\text { structure interpreted as hearths. They contained grey sand \& gravel } \\
\text { with inclusions of hazelnut, burnt bone and stone artefacts }\end{array}$ & \\
\hline Kinloch & $\begin{array}{l}\text { Numerous pits \& hollows that contained burnt flint \& charred } 2013 \\
\text { hazelnut shell. Feature BA1 also contained several fragments of } \\
\text { stone slabs, some of which could be rejoined \& were burnt, \& } \\
\text { were interpreted as 'hearth slabs' }\end{array}$ & Wickham-Jones 1990 \\
\end{tabular}


TABLE 1: (Continued)

\begin{tabular}{|c|c|}
\hline Site & Evidence \\
\hline Mount Sandal & $\begin{array}{l}\text { A possible hearth in the southern area consisting of a small } \\
\text { spread of charcoal at the base of the plough soil resting in a } \\
\text { shallow depression. } 4 \text { main hearths in the eastern area associated } \\
\text { with stake- } \& \text { post-holes } \& \text { interpreted as being in the centre of } \\
\text { a hut, potentially rebuilt on several occasions with a new hearth } \\
\text { on each occasion. The hearths consist of bowl-like pits cut into } \\
\text { the sandy soil, } c .1 .0 \mathrm{~m} \text { in diameter with depths of } 20-30 \mathrm{~cm} ; 2 \\
\text { of which had been recut. Hearth material appears to have been } \\
\text { transferred to pits adjacent to the structures. A further group of } \\
\text { small pits were filled with burnt stones, possibly having been } \\
\text { removed from the fires as hot stones for cooking or other } \\
\text { activities. }\end{array}$ \\
\hline
\end{tabular}

Howick Structure Phase A large irregular pit, up to $2.3 \mathrm{~m}$ in length, in the central area of Waddington 2007a; 2007b 1a the structure, containing large quantities of burnt flint, charred hazelnut shell, charcoal, fragments of burnt bone, \& was surrounded by heavily scorched sediment. The pit had numerous recuts indicating multiple burning events. The pit had an angled post-hole projecting from its base, interpreted as having held a post for fireside activities such as cooking. 2 later hearths had been cut into its deposits. 2 other large hearth pits were found to the east of this central hearth, also irregular in shape with evidence for posts, along with 2 much smaller pits containing burnt material

Howick Structure Phase Lying immediately above the primary hearths of Phase 1a there $1 \mathrm{~b}$ was an extensive burnt spread that covered the entire area of the hut. A hearth had been cut into this spread, containing burnt flints, charred hazelnut shell, scorched sand, \& occasional burnt bone. Another, with the same characteristics, had cut this hearth. An additional pit had been cut into the burnt spread. This contained hearth debris but with no evidence of in situ burning.

Howick Phase 2 hut 1 discrete hearth pit, $0.48 \mathrm{~m}$ in diameter and $0.17 \mathrm{~m}$ deep, containing charred material, fire-reddened sand, with charred hazelnut shell \& flints. There was also evidence for a succession of open fires in the central area (presumably within pits)

\begin{tabular}{lll}
\hline Howick Phase 3 hut & 2 hearth pits in the central area of the hut & Waddington 2007a; 2007b \\
\hline South Haw & $\begin{array}{l}2 \text { circular hearths in shallow pits containing burnt stones \& } \\
\text { charcoal. Possibly hearths consisting of burnt stone seemingly } \\
\text { positioned in a row \& on their sides }\end{array}$ & Chatterton 2007 \\
& &
\end{tabular}

Thatcham, Sites I \& II Several hearths, scraped out of the ground \&, in 1 instance, surrounded \& lined with large pieces of sarsen stone, associated with burnt flints, bone $\&$ antler, $\&$ charcoal

Nab Head II

A small \& shallow pit scoop, $40 \times 30 \mathrm{~cm}$, surface distinguished David 2007 by tightly packed angular stones between which there was a filling of burnt soil. Either a hearth or hearth sweepings

Avington IV

A pit $40 \mathrm{~cm}$ in diameter containing charcoal, calcined stones, \& Froom 2012

flint artefacts, surrounded by 3 circular structure made from
unworked flint cobbles, each $c .20 \mathrm{~cm}$ in diameter with 2 courses
of stone with hollow centre. Possibly used for supporting posts

flint artefacts, surrounded by 3 circular structure made from
unworked flint cobbles, each $c .20 \mathrm{~cm}$ in diameter with 2 courses
of stone with hollow centre. Possibly used for supporting posts

flint artefacts, surrounded by 3 circular structure made from
unworked flint cobbles, each $c .20 \mathrm{~cm}$ in diameter with 2 courses
of stone with hollow centre. Possibly used for supporting posts associated with the firepit

Woodman 1985

Wymer 1959; 1962

Waddington 2007a; 2007b

西


TABLE 1: (Continued)

\begin{tabular}{lll}
\hline Site & Evidence & References \\
\hline
\end{tabular}

Fireplaces within pits, and with evidence for a stone structure

\begin{tabular}{|c|c|c|}
\hline Staosnaig & $\begin{array}{l}\text { Two pit features (F41, F49) lined with stones adjacent to the } \\
\text { large circular pit (F24). F41 was oval with a gully, } 3 \times 1.5 \mathrm{~m} \text {. } \\
\text { The fill contained a high density of charred hazelnut shells. } \\
\text { Although the stones appeared not to have been burned, the } \\
\text { feature was interpreted as an oven for roasting hazelnuts with } \\
\text { the gully forming a flue. F49 was a } 0.98 \times 0.7 \mathrm{~m} \text { pit, } 0.2 \mathrm{~m} \\
\text { deep, with slate \& mica- schist forming a packing around its } \\
\text { western edge. The fill contained a high density of charred } \\
\text { hazelnut shells, leading to interpretation of a roasting pit. } 3 \\
\text { further pits (F43m F47 \& F51) lacked an evident stone structure } \\
\text { but may have had a similar function }\end{array}$ & Mithen \& Finlay 2000 \\
\hline Criet Dubh & $\begin{array}{l}\text { Hearth stones positioned in centre of shallow pit, likely to have } \\
\text { been recut on several occasions, over which there was a heavily } \\
\text { burned, organic rich sediment with charred hazelnut shell \& } \\
\text { burnt flint }\end{array}$ & Mithen \& Wicks 2018 \\
\hline Rubha Port an t-Seilich & $\begin{array}{l}\text { Accumulation of burnt stones originally positioned in crevice } \\
\text { between } 2 \text { outcropping slabs of bedrock, with horizontally laid } \\
\text { slabs around uppermost surface of the fireplace, with charred } \\
\text { hazelnut shell, charcoal, burnt flint, \& calcined fragments of } \\
\text { bone }\end{array}$ & Mithen et al. 2015 \\
\hline Cnoc Coig & $\begin{array}{l}\text { See above for hearths defined by well-defined patches of burning. } \\
\text { The larger hearths had clearly defined stone settings. The best } \\
\text { preserved were roughly circular arrangements of heavily burnt } \\
\text { beach cobbles arranged as a kind of rough paving in the central } \\
\text { area of the hearths. Small pits containing burnt cobbles were } \\
\text { found around the margins of the larger hearths }\end{array}$ & Mellars 1987 \\
\hline
\end{tabular}

\begin{tabular}{ll}
\hline Lussa Wood & A scoop made into gravel within which 3 adjacent stone rings \\
were constructed, each $c .1 \mathrm{~m}$ in diameter, with flat stone bases. & Mercer 1978 \\
Charcoal was present, but in limited quantity, with a number of \\
minute bone fragments. The excavator suggests this structure \\
might have been used for roasting meat
\end{tabular}

Morton Within Site A, a slightly scooped area delimited by burnt hearth Coles 1971
stones, dating to the earliest occupation. This was sealed by wind-blown sand $\&$ then succeeded by 2 hearth settings from occupation II. Artefacts tend to cluster around the hearths. Occupation III had a 'well-built' hearth, to the west of what was interpreted as a living floor with possible sleeping places. Within Site B there were several settings of stones which form either small hearths $0.2 \times 0.3 \mathrm{~m}$ across the central area with some charcoal, or supports for stakes $\&$ posts

\begin{tabular}{lll}
\hline Redkirk Point & A hollow/pit on the shore of the Solway Firth, $2.0 \times 3.0 \times 0.15$ & Canmore ID 67452 https:// \\
m deep, containing burnt sandstone pebbles \& charcoal, set & canmore.org.uk/site/67438/ \\
& within discoloured sand. A setting of stones was situated towards redkirk-point \\
the bottom of the hollow/pit. The charcoal was mainly from oak & \\
& \& elm, with some birch twigs & Radley \& Mellars 1964 \\
\hline Deepcar & 3 'relatively hard' areas within a purported structure were & \\
& interpreted as hearths. 1 has a ring of stones surrounding a & \\
& concentration of burnt artefacts \& another was bounded by \\
& stones on one side & \\
\hline
\end{tabular}


TABLE 1: (Continued)

\begin{tabular}{llc}
\hline Site & \multicolumn{1}{c}{ Evidence } & References \\
\hline Dunford Bridge Site B & $\begin{array}{l}\text { A small hearth, 0.23 m across \& } 0.2 \mathrm{~m} \text { deep, flat bottomed \& } \\
\text { full of sand, charcoal, \& burnt flints, with a compact stone } \\
\text { surround. The flint distribution is focussed on this hearth }\end{array}$ & Radley et al. 1974 \\
\hline March Hill & $\begin{array}{l}4 \text { hearths, with evidence for re-use on several occasions. Hearths } \\
1 \text { \& } 2 \text { were surrounded by stone settings; hearth 3 was set into a }\end{array}$ & \\
& $\begin{array}{l}\text { small depression; hearth 4 was the largest, with an elongated } \\
\text { shape. A fifth hearth was located 200 m away from this cluster }\end{array}$ & Froom 2012, 93 \\
\hline Wawcott IV & $\begin{array}{l}\text { The excavator describes 'a carefully constructed hearth, } \\
\text { approximately one meter is diameter, made from closely packed } \\
\text { sarsen stones' }\end{array}$ & \\
\hline Hawkcombe Head & $\begin{array}{l}\text { A shallow pit with charcoal inside a circle of stones, with loose } \\
\text { stone inside it. Predominately charcoal from oak, no flint } \\
\text { knapping debris \& located away from the clay floor of a } \\
\text { probable structure }\end{array}$ \\
\hline \hline
\end{tabular}

site to clean up refuse, or that the fireplaces themselves have left no direct archaeological trace. Sergant et al. (2006) have noted that 'invisible' hearths are characteristic of Mesolithic sites across north-west Europe and suggest this arises from a combination of the effectiveness of surface hearths - those without pits or stone structures - and post-depositional processes including trampling, water action, bioturbation, and erosion. Indeed, the fuel within a fireplace might burn to ash and then be blown or washed away leaving no archaeological trace. The ethnographic record is replete with examples in which diverse and complex economic and social activities revolve around fireplaces that are no more than surface hearths or shallow scrapes in the ground that would go undetected archaeologically.

Table 1 summarises the evidence from a sample of Mesolithic sites where the specific location of a fireplace has been proposed (Fig. 1). This sample comes from across Britain and throughout the Mesolithic period, although there is no attempt to provide a chronological distribution in light of the rarity of secure radiocarbon dates. Three categories have been used for the evidence:

1. Concentrations of burnt material and/or sediment that have been interpreted as the former presence of a fireplace (eg, Fig. 2);

2. Pits or natural depressions that contain burnt material/sediment (eg, Fig. 3);

3. Stone structures either enclosing or within an area of burning (eg, Figs $4 \& 5$ ).
It is reasonable to assume that the majority of the fireplaces in Table 1 had been used for cooking food and other practical activities. Some may have been used during day-light hours alone, and hence not been locations for the types of night-time fireside talk described by Wiessner (2014). Some general observations about the data-set can be observed.

\section{Inconsistent terminology, descriptions, and limited ability to identify the size of the past from its residues}

There is an absence of both shared terminology and methodology for describing such features. Terms such as fireplace, hearth, and fire-pit are ill-defined and appear inter-changeable, while the variation with which such features are described compromises effective comparisons. This is partly a consequence of our limited understanding concerning the formation of the archaeological evidence for fireplaces. When faced with a well-defined cluster of burnt material such as at Bexhill (Fig. 2), we have little idea of the scale of fire from which this might have derived. Does it reflect a transitory fire used by just one or two people, or might it derive from a more substantial fire used as the focal point for a social gathering? Similarly, one might ask about the nature of the fire - its duration and fuel - required to create a deposit such in the hearth-pit at Howick (Fig. 3). The need for systematic programmes of experimental archaeology, building on work undertaken by Score and Mithen (2000), Sergant et al. (2006), and Lejay et al. (2016) is evident. 


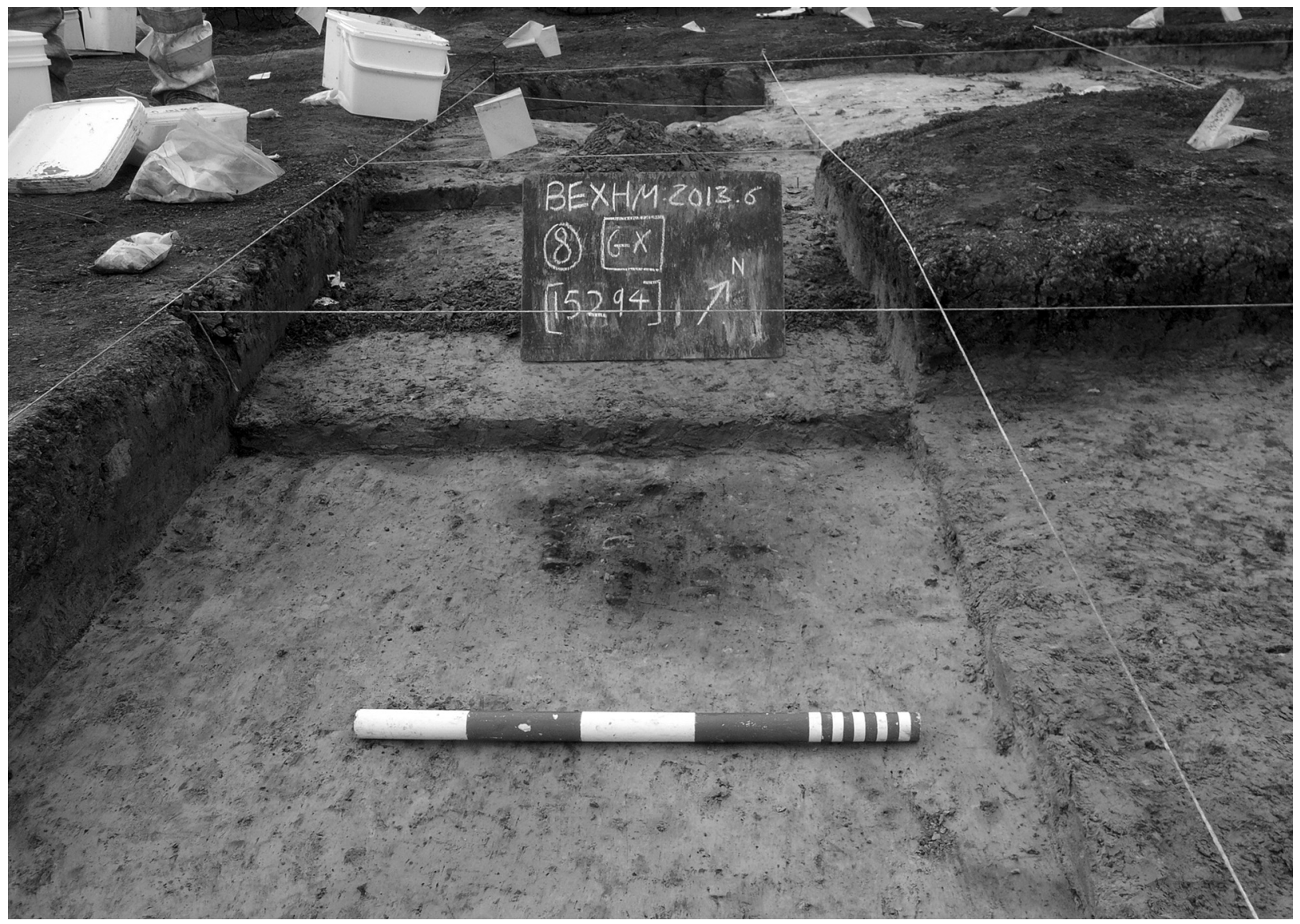

Fig. 2.

Concentration of burnt material representing a fireplace at Bexhill (image: Mike Donnelly, () Oxford Archaeology)

Fireplaces can become spatially distributed

Clusters of fire-cracked stones, such as at Goldcliff, might arise from hot stones having been removed from a fireplace for use elsewhere and then deposited away from the fireplace itself. Similarly, a concentration of burned bone might have arisen from the removal of cooked meat for consumption away from the fireplace. We can be more confident that discrete concentrations of burnt flint indicate the locations of fireplaces in light of experimental evidence indicating flint artefacts only become burnt when in direct contact with the fire itself (Sergant et al. 2006) and the unlikelihood they would be moved. Mixed concentrations of burnt material, whether on the surface or in pits, might be hearth sweepings rather than the fireplace itself. The midden-related sites on Oronsay and at Morton have pits containing likely hearth sweepings, while both Mount Sandel and Cnoc Coig have small pits close to the fireplaces into which burnt stones were placed.

\section{Constructed fireplaces are rare in the archaeological record}

Despite the evidence for concentrations of burnt material, that for constructed fireplaces is surprisingly rare, by which I mean fires made within pits and/or with stone structures. Fireplaces within a stone surround are strikingly rare. Differentiating between stones used to construct a fireplace and those heated within a fireplace for use in cooking, and possibly taken away from the fire, is often difficult. Any one stone might have played both roles, and hence a stone built fireplace might become entirely dismantled by the end of a cooking event. Those present are primarily from northern Britain: in Scotland and the Pennines, 


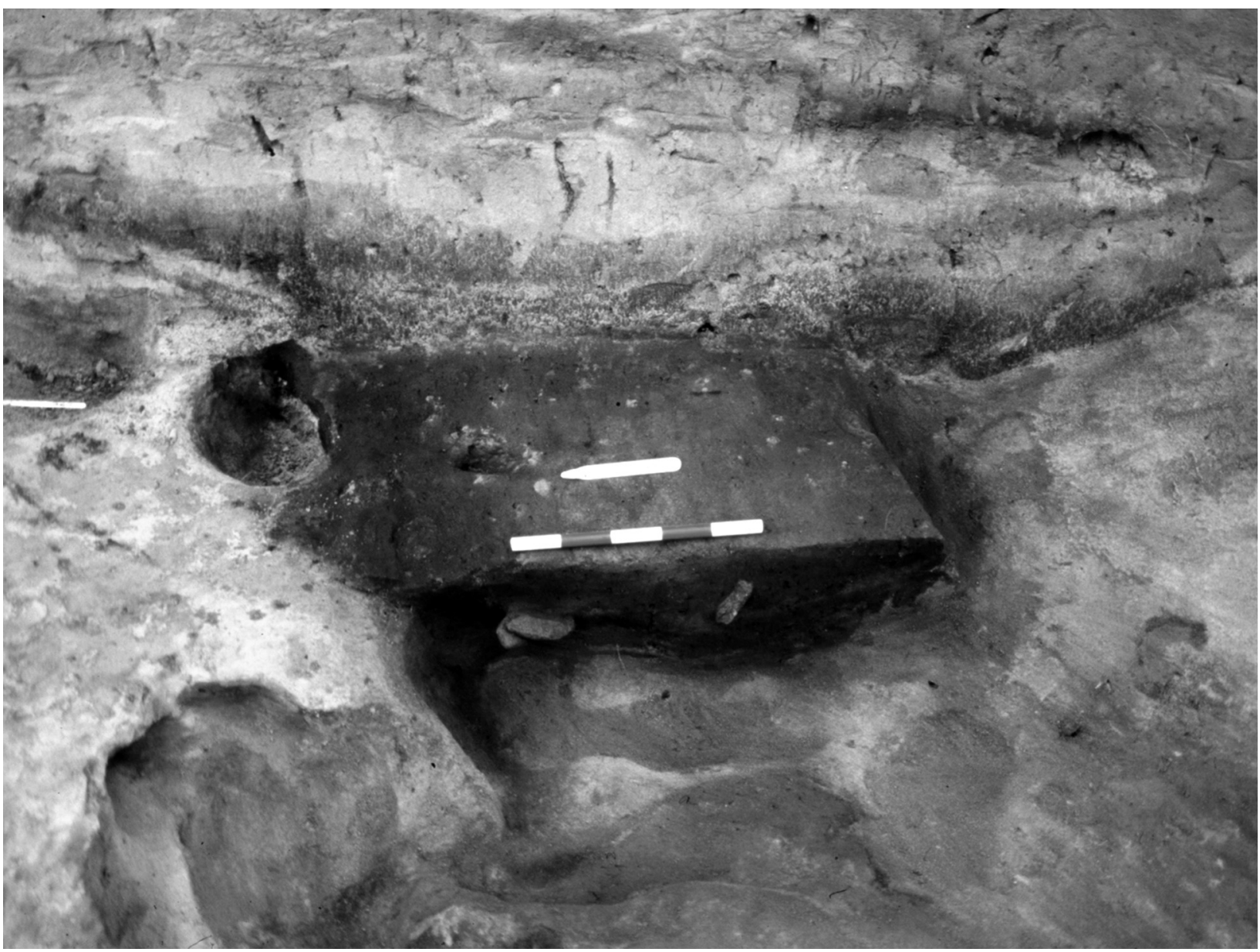

Fig. 3.

Pit containing fireplace, Feature 357, at Howick Phase 1a (image: Clive Waddington)

with outliers at Hawcombe, Somerset, and Wawcott IV, Berkshire. The limited evidence for constructed fireplaces at Star Carr is notable in light of the interpretations for ritual at this location, presence of wood platforms, and the extensive area of excavation (Conneller 2004; 2005; Chatterton 2006; Milner et al. 2018). This matches the absence of substantial-sized dwelling structures at Star Carr when compared with other Mesolithic sites (Mithen \& Wicks 2018), further indicating the extent to which Star Carr is anomalous for the British Mesolithic.

\section{The most substantial fireplaces are found within structures}

The most substantial fireplaces are those within structures, notably at Mount Sandel and Howick, that have been referred to as 'pit-houses' (Waddington \& Bonsall 2016, 216). As Waddington (2015) argued, Howick and Mount Sandel might relate to a period of secondary colonisation of northern Britain, and hence the structures and fireside activities might have been key to the initial stages of landscape enculturation, such as those described above for the Kesyehot'ine Chipewyan hunter-fishers. In light of the ethnographic record indicating the effectiveness of a flat surface or a shallow pit as a fireplace, and the prevalence for fireplaces to be outside of shelters, one is inclined to think these internal, structured fireplaces might have had a ritual rather than routine purposes. The pit-houses might have been dedicated to social and ceremonial activities, possibly a type of sweat lodge (Waddington et al. 2007; Mithen \& Wicks 2018). 


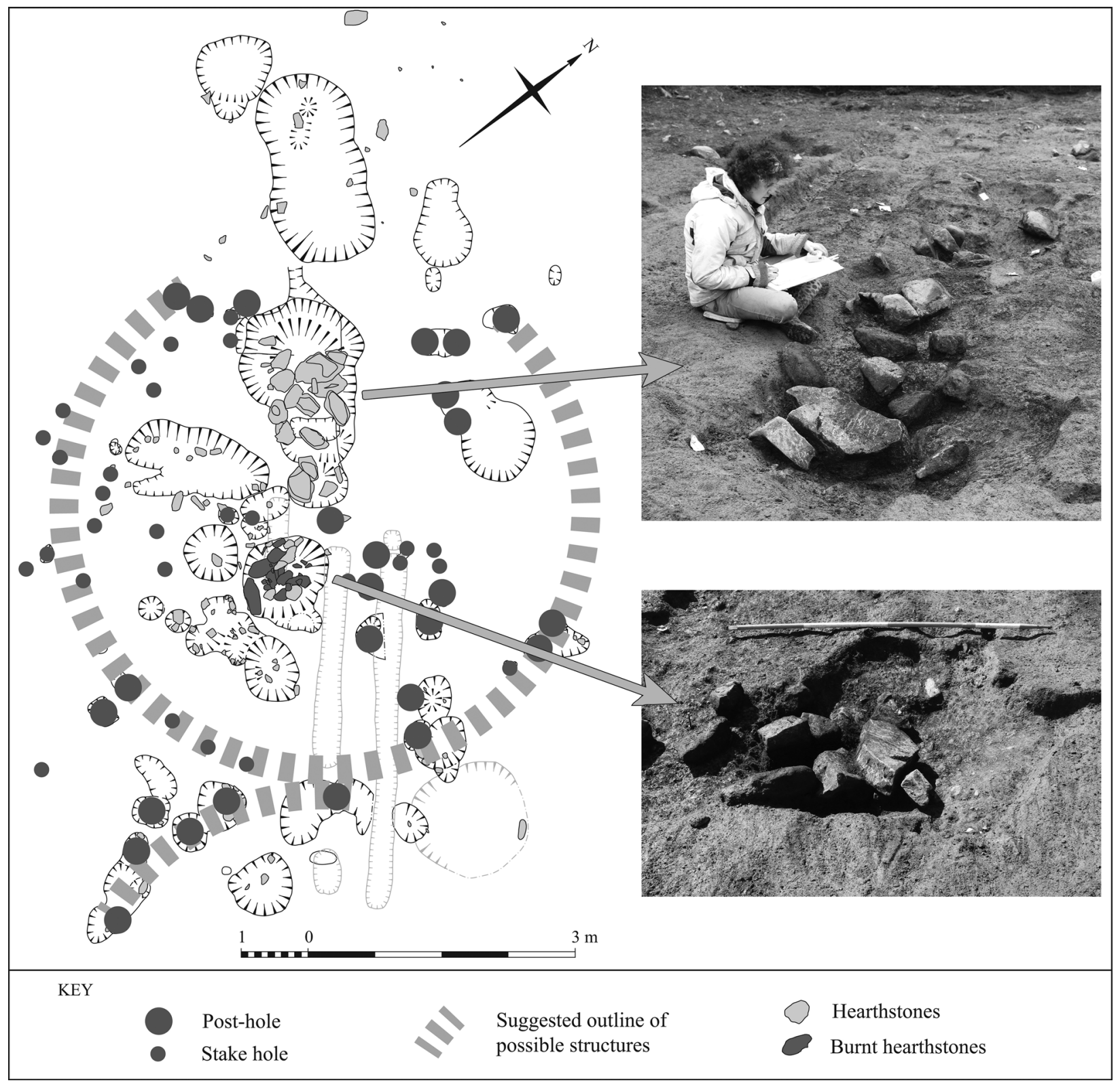

Fig. 4.

Fireplace with stone structure, Criet Dubh, Isle of Mull (image: Steven Mithen)

Features that may have been large fire-pits might be interpreted as fires used for special rituals, analogous to those described by Marshall (see above, 1976) for the !Kung. The concentrations of burnt flint in the centre of pits at Farnham were interpreted as hearths within dwelling structures (Clark \& Rankine 1937-8). This site deserves revisiting because the absence of features such as post-holes and the high frequency of burnt flints throughout the deposits questions this interpretation. The Farnham pits appear similar to that at Staosnaig (Mithen et al. 2001; compare Clark \& Rankine 1937-8, pl. viii with Fig. 8 below), suggesting an alternative interpretation of their use as large fire-pits rather than as dwellings. 

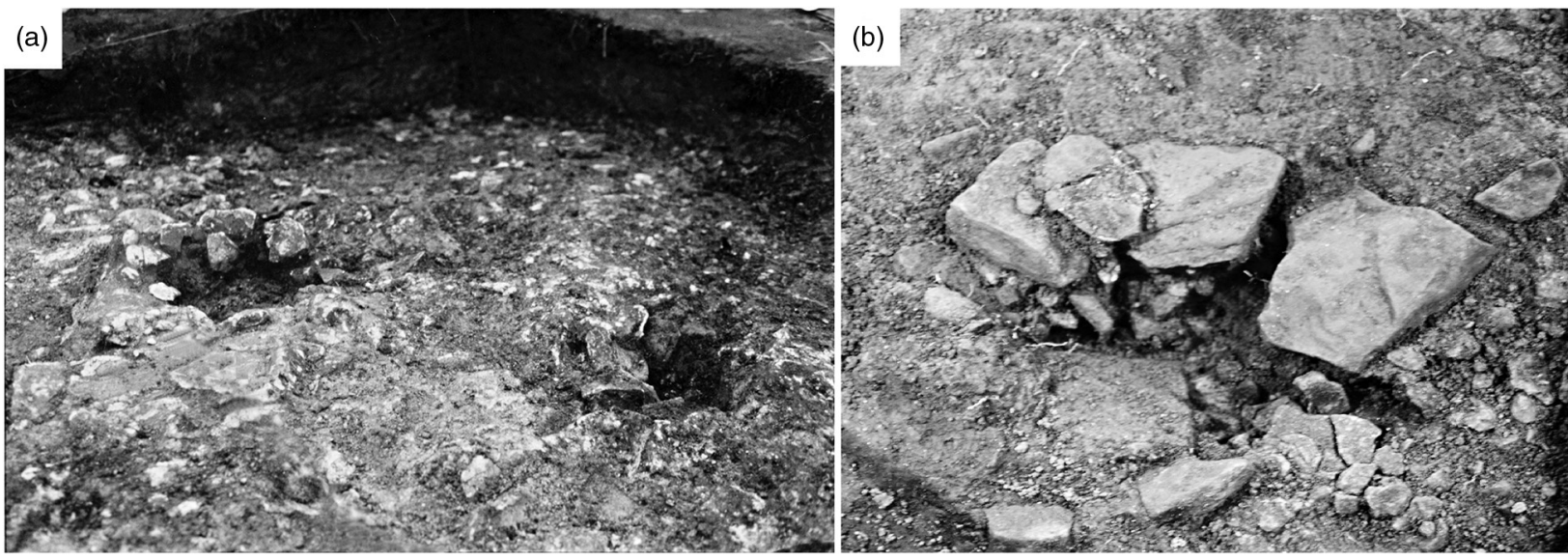

Fig. 5.

a. Hearths 1 \& 2, March Hill Carr site A, facing south; b. Hearth 1, March Hill Top Site B (image: Penny Spikins)

\section{Fireplaces often show evidence for repeated use}

The fireplaces at Howick, Mount Sandel, and Criet Dubh show a pattern of repeated usage. One suspects this might be the case from elsewhere were further examples of fireplaces with multiple radiocarbon dates available. The repeated use of the same fireplace, or a discrete location for fireplaces, is also evident from the midden-related sites on Oronsay and at Morton. These have fireplaces built directly on top of previous ones, in some cases following the deposition of windblown sediment, and dense clusters of small hearths. Whereas Mithen and Wicks (2018) suggested that the recurrent occupation at Howick, Mount Sandel, and Criet Dubh was for the re-use of the structures, a more likely scenario is the re-use of the fireplace - sitting and telling stories where recent relatives and distant ancestors had sat and done the same. The structures themselves would have likely deteriorated beyond use in the elapsed periods between occupations. As with the Selk'nam and the !Kung, the fireplace was likely to have been far more essential to a sense of place, social cohesion, and survival than temporary huts and windbreaks (Marshall 1976; Spikins et al. 2010).

\section{The ubiquitous presence of on-site fire usage}

Despite the challenging nature of this evidence, its key significance is simply the ubiquitous presence of fire whether represented by fireplaces or by dispersed burnt material - on Mesolithic sites. Interpretations of specific fireplaces from the archaeological record will always be problematic because hunter-gatherers are prone to leave behind 'such a variable number of piles of ash from fires that had such a variety of purposes' (Marshall 1976, 91, writing about !Kung encampments). Nevertheless, recognising that fireplaces were not only used for cooking and practical activities, but also as loci for story-telling, singing, and ritual, activities that enculturated the surrounding landscape, provides us with a more holistic view of Mesolithic life - even if the specific activities and meanings attached to the landscape remain unknown. Further insights might arise by considering the fireplaces within the topography of the landscape and in the context of known subsistence activities and settlement patterns.

\section{A CASE STUDY FROM WESTERN SCOTLAND}

My area of particular interest is the southern Inner Hebrides, with its principal islands of Islay, Jura, Colonsay, Oronsay, Mull, Coll, and Tiree, and the seaways between these islands and the mainland (Fig. 6).

Numerous Mesolithic sites are known within this region. Proposing how this land- and seascape might have been enculturated, and what specific features might have been attributed with meaning, inevitably involves conjecture because, as noted above, the social history and cosmology of the Mesolithic is entirely lost to us. Nevertheless, unless one makes such proposals, any account of the Mesolithic will remain partial and we will fail to challenge our own interpretations of the evidence - that is the Mesolithic archaeologist's dilemma, which becomes acutely evident within this study region. A pre-requisite is to embed such 


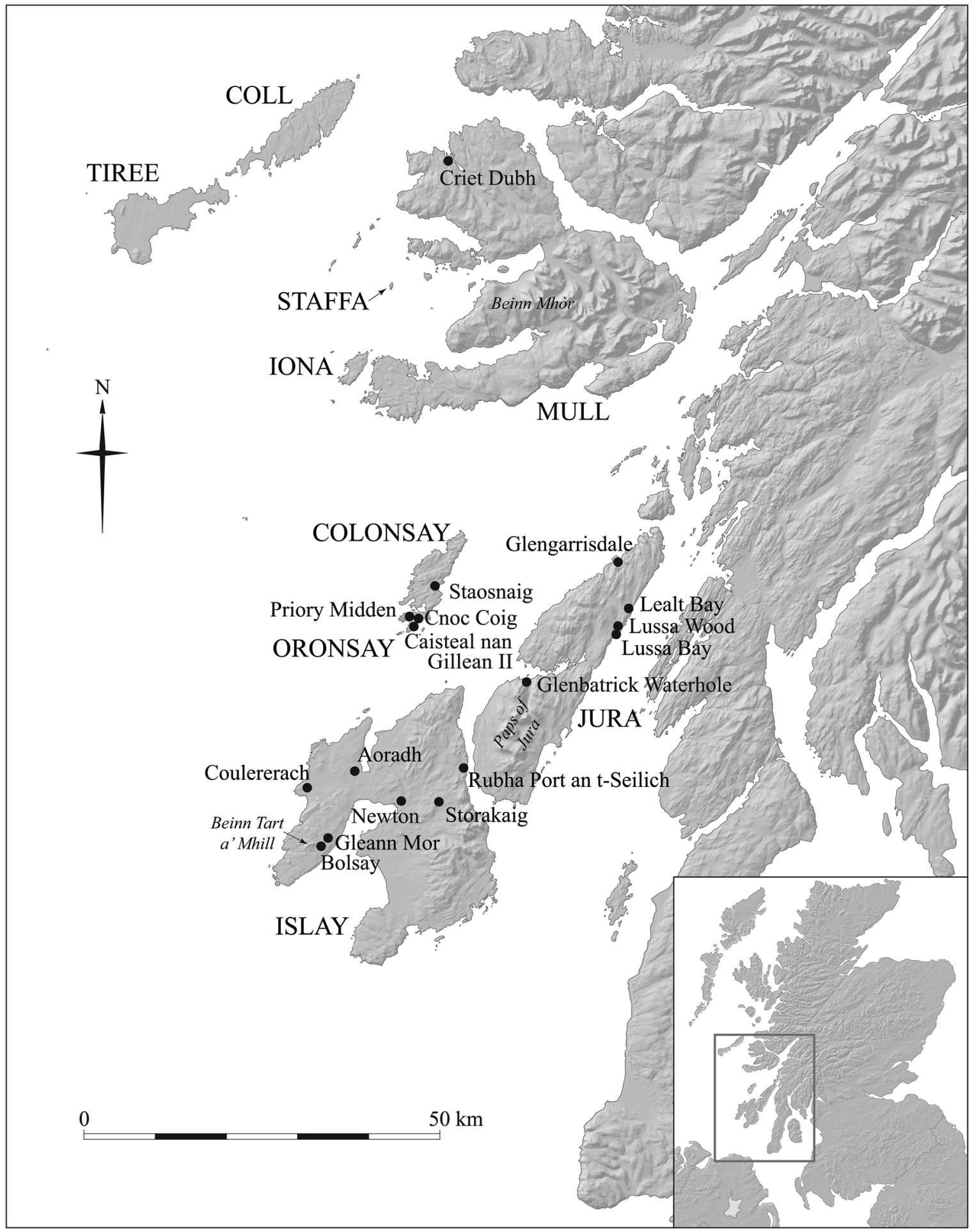

Fig. 6.

Map showing distribution of Mesolithic sites and selected natural features in the southern Inner Hebrides 
proposals in a thorough knowledge of the archaeological evidence: having undertaken survey and excavation within the region over a 30 year period, I trust I might have leeway to step beyond what can be securely inferred from the archaeological data alone.

\section{Current and historic meanings on the landscape}

As is often the case, the present-day and recent history can provide a guide to the more distant past. The present-day land/seascapes of western Scotland are subject to many layers of meaning, these varying between different interest groups such as farmers, estate owners, whisky distillers, tourists, wildlife experts, seafarers, archaeologists, and so forth. My experience of working in this region is that every patch of land and sea has stories about it, often told differently by different people.

Place-names are principally in Gaelic and indicate a further layer of meanings, many of which are now lost. While the names and associated stories themselves are unlikely to be relevant to the Mesolithic, that being so distant in time, they nevertheless indicate topographic locations that are prone to being attributed with social and symbolic significance. On Islay, for instance, the prominent peak on the western Rhinns peninsula is Benin Tart a 'Mhill (232 m), translated sometimes as 'mountain of drought' (Ferguson \& Perrons 1988) and sometimes as 'stag hill' (Caldwell 2008, 139). This peak illustrates on-going enculturation with the burial of a young man (Rod Dawson) on its summit in 1977 followed, in the 1980s, by the positioning of a communication mast for civil aircraft. Some place-names appear descriptive of the natural world: Ard Imersay is the 'promontory of the emmer goose', and Ballaiblaven the 'Township of the buzzard'. Other place-names allude to historical events. Carnduncan, for instance, is the burial place of Duncan, the foster-son of Sir Lachland Mor MacLean, the 14th Chief of Duart. As recounted in the story of the 1598 Battle of Traigh Ghruineard, Duncan was killed by his own mother after he had laughed at the bobbing head of MacLean's corpse when being taken from the battlefield for burial. She killed and buried Duncan below a heap of stones that became 'Cairn of Duncan'. In 'reality', Carnduncan is a Bronze Age cairn (RCAHMS 1985, 52). The stories associated with other place-names are entirely lost: Loch Conilbhe means 'Loch of the Goddess' and Loch Drolsay means
'Loch of the Trolls'. Other names hint at past social occasions: Aoradh means 'place of sun worship' and Sunderland probably means 'assembly place by the loch' (Ferguson \& Perrons 1988).

The most striking peaks in the whole region are the Paps of Jura - three conical peaks $700-800 \mathrm{~m}$ in height. These not only dominate their immediate surroundings but also form part of the seascape for many miles around, being prominent landmarks from Kintyre, the islands of Colonsay, Mull, Tiree, and Coll, and even from the tower blocks of Glasgow (Youngson 2001). The origins of and stories associated with their Gaelic names are unknown: Beinn an Or $(785 \mathrm{~m})$, the 'Peak of Gold', Beinn Shiantaidh $(755 \mathrm{~m})$, the 'Peak of Storms', and 'Beinn a'Chaolais $(734 \mathrm{~m})$, the 'Peak of Narrows or Sound'. The highest peak of the region is Beinn Mhòr (966 m) on the Isle of Mull, meaning 'Great Mountain'. Another prominent feature of the region is the Gulf of Corryvreckan, meaning 'cauldron of the speckled seas' or 'cauldron of the plaid', about which there are many stories (Youngson 2001, 172-5). Located in the narrow strait between the islands of Jura and Scarba, Corryvreckan has energetic whirlpools and tidal currents. In one account, the goddess of winter, Cailleach Bheur, uses the gulf to wash her great plaid, which ushers in the turn of the seasons from autumn to winter. As winter approaches, her cloth is washed pure white and becomes the blanket of snow that covers the land.

\section{The Mesolithic economy and landscape enculturation}

The Mesolithic economy involved hunting terrestrial and sea mammals, including red deer, wild boar, otters, and seal, as evident from the faunal remains from Oronsay middens, Storakaig, and the Rubha Port an t-Seilich (Mellars 1987; Wicks et al. 2014; Mithen et al. 2015). The coastal location of numerous sites and evidence from Oronsay and Fiskary indicate in-shore fishing and collection of coastal resources, including shellfish and crabs (Mellars 1987; Wicks $\&$ Mithen 2017). Charred hazelnuts are ubiquitous at Mesolithic sites and found in especially large numbers at Staosnaig, along with crab apple and lesser celandine (Mithen et al. 2001). There is compelling evidence from Islay and Mull for the use of fire for vegetation clearance and, potentially, other forms of landscape management (Edwards 2000; McCullagh 1989; Edwards et al.2007) 


\section{S. Mithen. MESOLITHIC FIREPLACES \& ENCULTURATION, EARLY HOLOCENE, BRITAIN}

The fireplaces found at several of these Mesolithic sites (Table 1), and inferred at others by the presence of burnt material, would have been essential for preparing food and other practical tasks. Their number and character suggest they had also played a role in social activities. One of these is likely to have been communicating whereabouts, because night-time fires would have been seen from long distances, certainly from one island to another as is the case with electric lights today. Night-time fires would have also played a role in the enculturation of the landscapes.

The enculturation of the Hebridean land-/seascape is likely to have begun in the Late Pleistocene (c. 12,000 cal BP) in light of a tanged point and Ahrensburgian-like technology from Rubha Port an $\mathrm{t}$-Seilich on the east coast of Islay (Mithen et al. 2015; Berg-Hansen et al. 2019). Such exploration likely originated from the northern margins of Doggerland and followed around the north and west coast of Scotland in light of the distribution of tanged points on Orkney, Shieldig, Tiree, and Islay. The first radiocarbon dated activity is at $c .10,230 \mathrm{cal} \mathrm{BP}$ at Criet Dubh, Isle of Mull (Mithen \& Wicks 2018). Landscape enculturation during such exploration and pioneering settlement may have followed similar stages to those of the Kesyehot'ine Chipewyan when moving from the sub-Arctic into boreal forest, as described above. It is reasonable to assume that prominent landmarks and seamarks such as the Paps of Jura and the Gulf of Corryvreckan were named during this period.

Land-/seascape enculturation would have continued as the intensity of Mesolithic activity increased to a maximum at $c .8200 \mathrm{cal} \mathrm{BP}$, as measured by a peak in the summed calibrated probability distribution of radiocarbon dates (Wicks \& Mithen 2014). The abrupt climatic event at that date appears to have caused population collapse in light of the dramatic reduction in activity. This suggests the Mesolithic population had always been relatively low and sensitive to environmental change, as further indicated by the tempo of activity at Criet Dubh (Mithen \& Wicks 2018). To use Lovis's (2016) term, the region is likely to have been a 'big rough space with few people'. As such, landscape enculturation would have been a priority for maintaining social networks. Mesolithic activity gradually increased again after $c .8000 \mathrm{cal} \mathrm{BP}$, before coming to an abrupt end by the arrival of the Neolithic at c. 5600 cal BP (Wicks \& Mithen 2014).

\section{Fireplaces and their interpretation}

Rubha Port an t-Seilich has one of the most substantial fireplaces from the British Mesolithic (Fig. 7). Constructed within the shelter of two outcrop boulders of rock, its earliest deposits correspond with the horizon of the Ahrensburgian-like artefacts. The fireplace consists of burnt stone, charcoal, charred hazelnut shell, and burnt artefacts that accumulated throughout a long succession of site visits, the last of which is currently centred on c. $7880 \mathrm{cal}$ BP (Mithen et al. 2015; Mithen et al. in press). Stone slabs were placed around the fireplace, between which discrete clusters of flint tools and debitage were found, along with coarse stone tools, fragments of calcined animal bone (primarily from red deer), charcoal, and charred hazelnut shell. Sergant et al. (2006) note that temperatures of $700^{\circ} \mathrm{C}$ are required to calcinate bone whereas cooking requires $250^{\circ} \mathrm{C}$ at a maximum. As such, the bone fragments at Rubha Port an t-Seilich seem unlikely to be the product of accidental burning during cooking. The use of bone as fuel also seems equally unlikely in light of the availability of wood, evident from the charcoal present, dominated by birch and hazel. One is drawn, therefore, to make comparisons with the use of fire to make ritual transformation of hunted animals into products suitable for consumption, as undertaken by the Siberian Iukagir hunters when they use fire to convert an animal from the social to the natural world (Willersley 2010).

The ecological attraction of Rubha Port an t-Seilich is reasonably intuitive: rocky outcrops into the strait separating Islay from Jura provide landing places for small boats travelling either south or north. The straits themselves provide a routeway connecting Kintyre with the islands of Mull, Colonsay, Oronsay, Coll, and Tiree - it seems no coincidence that Rubha Port an t-Seilich is located just a kilometre from the modern ferry terminal of Port Askaig. The location provides access to marine and coastal resources, and terrestrial woodland for hunting and gathering on both Islay and, immediately across the narrow straits, the Isle of Jura. With regard to Rubha Port an t-Seilich as a location for story-telling and other types of enculturation activities, one must note that it faces north-east, across the straits to Jura and its three Paps (Fig. 8). We cannot know whether these were spiritually charged in the Mesolithic but it would be obtuse to think otherwise. 

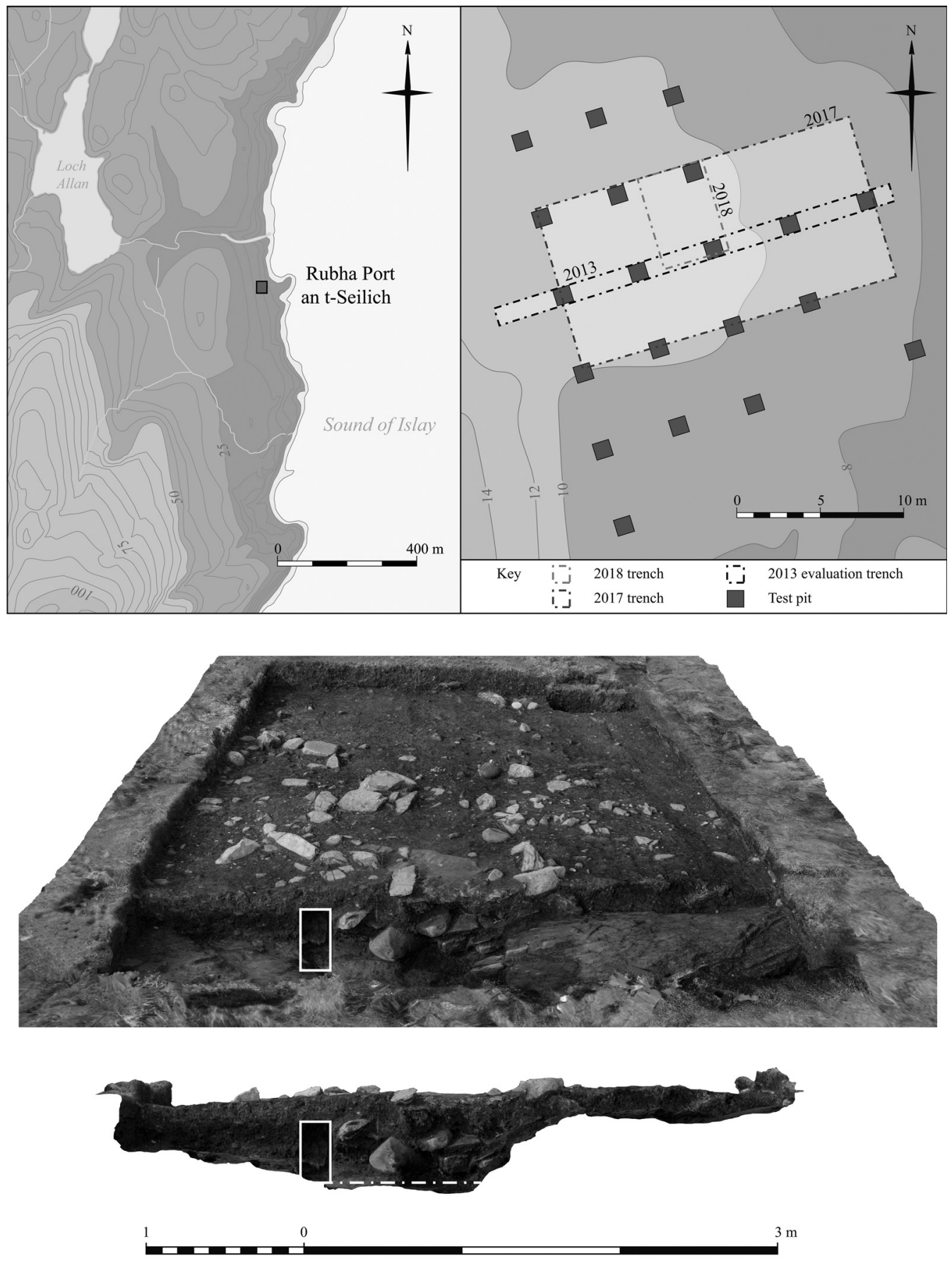

Fig. 7.

Mesolithic fireplace at Rubha Port an t-Seilich, Isle of Islay. The white outline indicates the location of a block removed for micromorphological analysis, as described in Mithen et al. 2015 (images: Steven Mithen) 
S. Mithen. MESOLITHIC FIREPLACES \& ENCULTURATION, EARLY HOLOCENE, BRITAIN
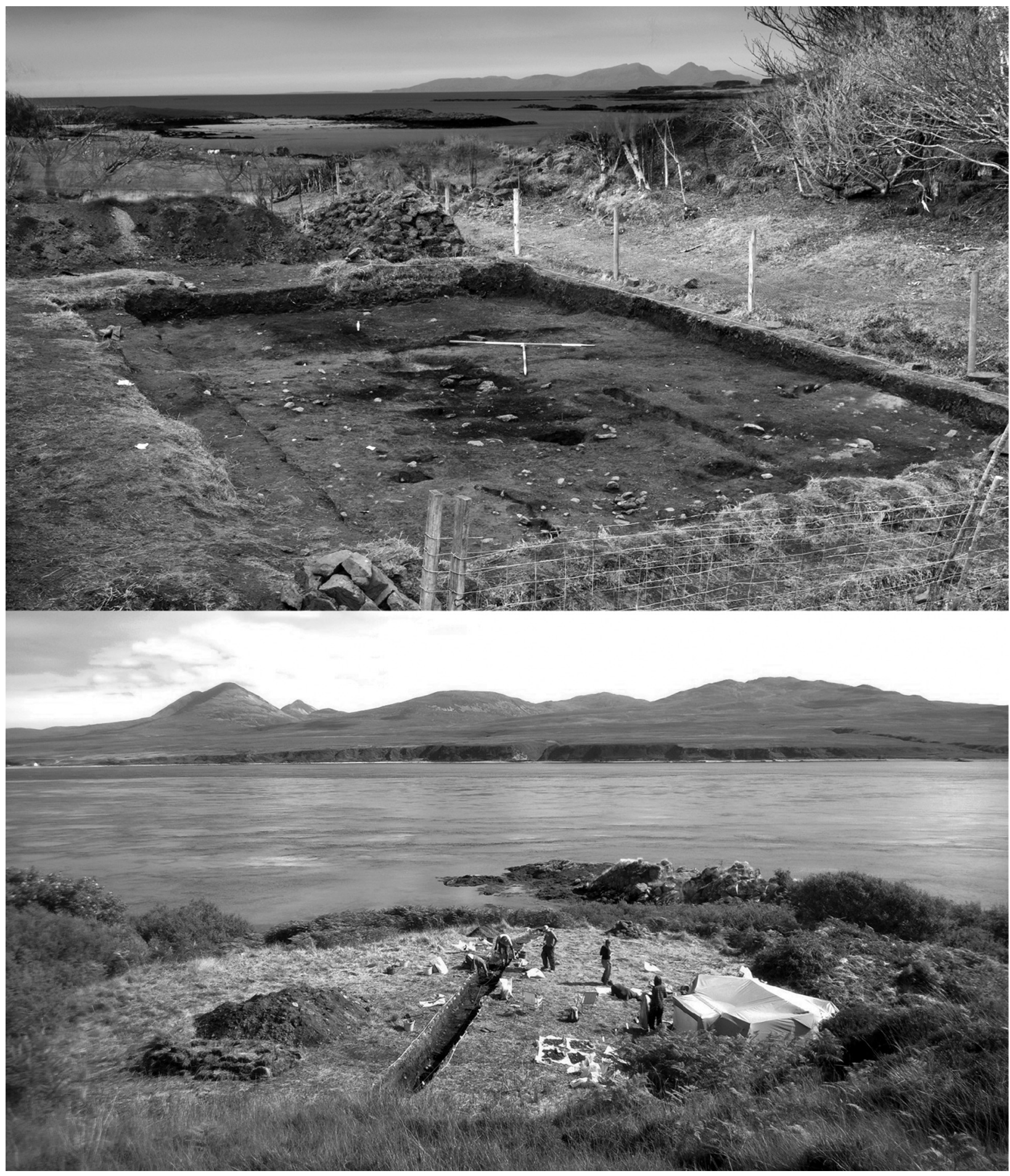

Fig. 8.

Views from fireplaces at Rubha Port an t-Seilich towards the Paps of Jura, \& from Criet Dubh towards the Isle of Rum (images: Steven Mithen) 


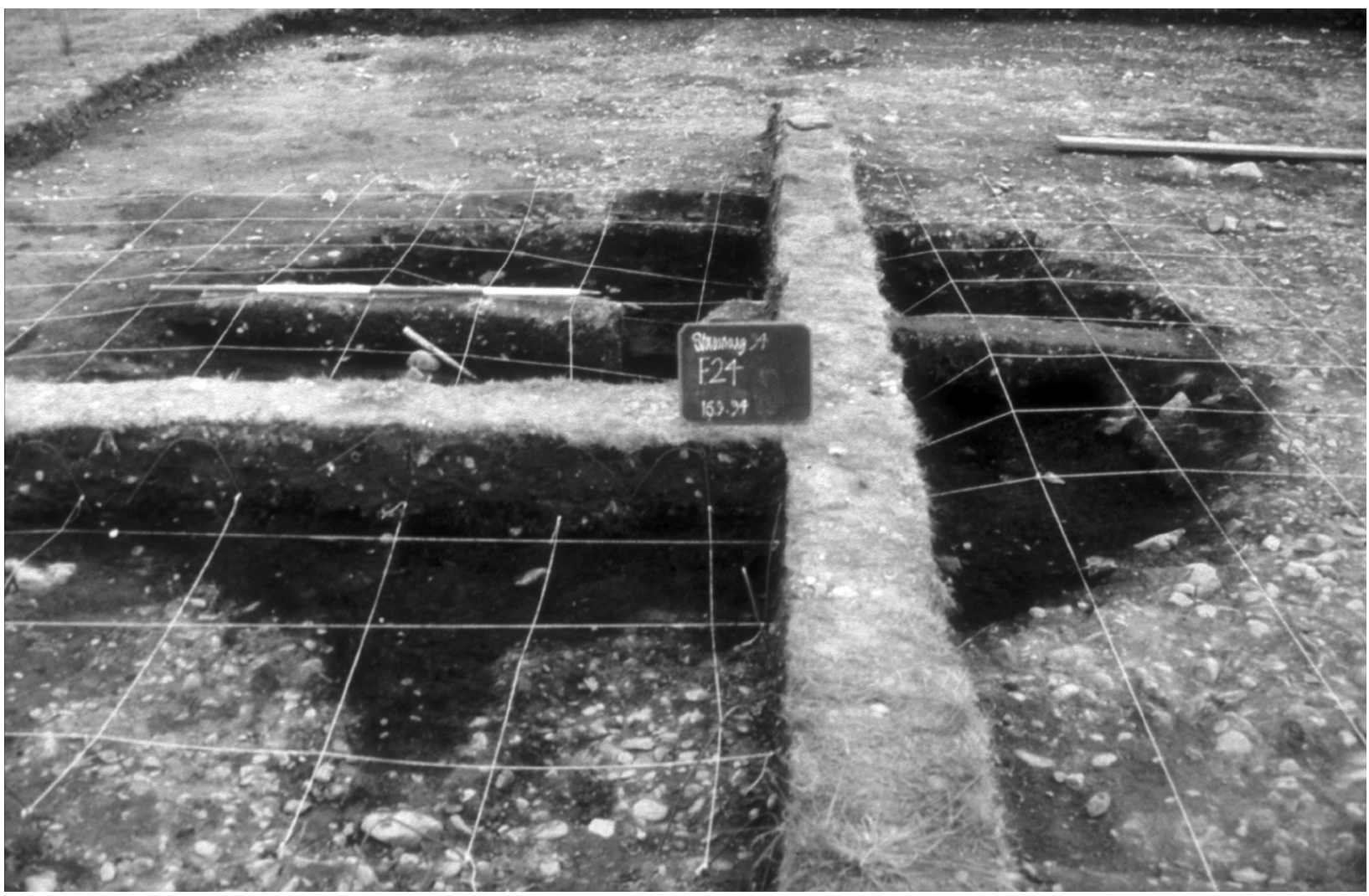

Fig. 9.

Feature F24, Staosnaig, Isle of Colonsay (image: Steven Mithen)

Another impressive fireplace is located at the site of Criet Dubh on the Isle of Mull (Mithen \& Wicks 2018; Fig. 4). This contained unshaped blocks of burned stone within shallow pits, covered in heavily burned deposits. Stakes and posts had surrounded the fireplace, but their truncation by recent cultivation leave the type of structure they represent unclear windbreaks, a hut, a smoke house, or even a minisweat lodge? Radiocarbon dating of the deposits that had accumulated around, over, and in-between the hearthstones and from the immediately adjacent features indicate that Criet Dubh had been visited and the fireplace used on multiple occasions between c. $10,230 \mathrm{cal}$ BP and $8580 \mathrm{cal} \mathrm{BP}$. A structure, probably less substantial than the later hut, had been built early in this sequence of visits, perhaps providing the type of artificial marking of the landscape undertaken by the Kesyehot'ine Chipewayan as an integral part of their enculturation of a newly colonised landscape. An attractive ethnographic analogy for the later hut is that provided by the Selk'nam for the male initiation ceremony. This involved a 'Hain' hut constructed away from the settlement exclusively for men. It contained a central fireplace from which spirits would rise from the spirit world into the hut (Spikins et al. 2010).

As at Rubha Port an t-Seilich, the ecological attraction of Criet Dubh is intuitive: the site is adjacent to an estuary that would have provided outstanding opportunities for fishing, fowling, and foraging, and at the shortest crossing point to the Isle of Coll. Another similarity with Rubha Port an t-Seilich is that the vista from Criet Dubh is towards some of the most notable peaks in the region - the distinctive and dramatic mountains of the Islands of Rum and Skye (Fig. 8).

Staosnaig, Isle of Colonsay, provides another impressive fireplace, albeit one that has remained unrecognised as such (Fig. 9). A $4.5 \mathrm{~m}$ diameter circular shallow pit contained more than $15 \mathrm{~kg}$ of charred hazelnut shell fragments, estimated to have come from 30-40,000 hazelnuts (Mithen et al. 2001), arising from at least six visits to the site between c. 9060 cal BP and $6230 \mathrm{cal}$ BP. The smaller surrounding 


\section{S. Mithen. MESOLITHIC FIREPLACES \& ENCULTURATION, EARLY HOLOCENE, BRITAIN}

features may have been ovens for roasting hazelnuts and other plant foods, potentially reused as fireplaces. Experimental roasting charrs $12-25 \%$ of hazelnuts, which destroys the kernel (Score \& Mithen 2000). Had it just been such charred waste discarded into the large pit, then at least 300,000 hazelnuts would have been roasted at Staosnaig. It seems more likely that people had deliberately gathered the shells from all the roasted hazelnuts - charred or otherwise for deposition and burning in the pit. Why do this? Why not simply leave them on the ground to be washed or trampled away? The answer may have been to create a mass of glowing embers and a cloud of aromatic wood smoke at a fireplace that also provides a south-easterly view towards the Paps of Jura. One cannot resist thinking about the use of wood-smoke by the Chukchis reindeer herders, to keep the male reindeer strong and virile during the rutting season (Vaté 2010). Equally, the large central fire-pit with smaller adjacent fireplaces invokes Marshall's $(1976,91)$ description of special fires for ritual activities amongst the !Kung around which dancing takes place, during which those who are not dancing sit at small fires near the dance circle.

There are further significant fireplaces within this study region (Table 1). Those at the Oronsay middens and the extensive burnt deposits at Storakaig (Isle of Islay), with heavily calcined bone, have been noted above. A large pit not dissimilar to that at Staosnaig was excavated at Newton (Isle of Islay) and a structure consisting of three stone rings at Lussa Wood on Jura is likely to have been a fireplace (Mercer 1978).

\section{Mobility and subsistence in an encultured landscape}

We are unable to infer the specific meanings, cosmological and otherwise, that Mesolithic people attached to their land-/seascapes. It would be surprising if those prominent features conferred with meanings in historic times had not been considered likewise in the Mesolithic. The sea-travelling explorers and pioneers would surely have encountered the whirlpool now known as the Gulf of Coryvrecken and given it a name. The vistas from Rubha Port an t-Seilich, Criet Dubh, and Staosnaig have already been noted. More generally, Mesolithic sites were positioned to have a more wide-ranging view across the landscape than would have occurred by chance (Lake et al. 1998). While of value for watching for game, and observing the natural world in general, this might also reflect the cosmological and social meanings of the landscape.

There is a huge accumulation of Mesolithic stone artefacts on the lower slopes of Benin Tart a 'Mhill at the site of Bolsay (Mithen et al. 2000a). This is a palimpsest from multiple visits to what was most likely a red deer hunting camp, with concentrations of burnt flint indicating many small fireplaces. It is difficult to resist analogies with the attraction of the Blackfoot Indians to the Sweetgrass Hills (now in Montana). This was also a prominent landmark, to which they regularly returned for hunting, in their case of buffalo. The Sweetgrass Hills were also integral to Blackfoot cosmology and their camping sites not only met subsistence needs but also provided a location for spiritual activities in preparation for religious ceremonies. The same might have been the case for the Mesolithic hunters who visited Bolsay. We should note the continued use of Bolsay into the Neolithic with the loss/deposition of a polished stone axe and the construction of a Neolithic chambered cairn in its close vicinity (the 'Giant's Grave', RCAHMS $1985,50)$, as well as the only stone circle on the island (Cultoon, RCAHMS 1985, 66-7). Both Tilley (1994) and Bradley (2000) have cited the deposition of artefacts and construction of later monuments as possible indicators of the sacredness of a natural place in the Mesolithic.

It is tempting to think that the Gaelic place-names might reflect inherent properties of place and possibly the long-term continuation of activities. The hunting camp at Bolsay seems appropriately positioned at the base of a hill known as 'Stag Hill', while Rubha Port an t-Seilich has been translated as 'point of the hunter'. A Mesolithic site, interpreted as an observatory for wildfowl and game, is known at Aoradh (Mithen et al. 2000b): the 'place of sun worship'.

More generally, the notion that the journeys across and between the islands and mainland of this study area were fulfilling historical, social, and cosmological imperatives as well meeting subsistence and other needs is compelling. While visits to Coulererach on the west coast of Islay might have served to acquire flint pebbles (Mithen \& Finlay 2000), this coastline has a dramatic topography and was charged with value from at least the Neolithic onwards in light of monuments such as the Balinaby standing stone and a later Viking burial (RCAHMS 1985).

The meeting of social and/or cosmological obligations may have provided the motivation for the 
repeated visits to small islands such as Oronsay, Colonsay, Oronsay, and Coll that would have required treacherous and lengthy sea crossings. While resources on such islands may have been of value, it seems unlikely that the benefits gained would have offset the costs and risks of sea-travel when the same types of resources were also available on the larger islands and mainland. The sets of radiocarbon dates from these the small-island sites suggest such visits had been infrequent. At Fiskary on the Isle of Coll, for instance, the available radiocarbon dates $(n=6)$ suggest three visits (or short sequences of visits) centred on $9070 \mathrm{cal} \mathrm{BP,} 8520 \mathrm{cal} \mathrm{BP}$, and $8280 \mathrm{cal} \mathrm{BP}$, which are several generations apart (Wicks \& Mithen 2017). From an ecological perspective, this may have fulfilled the need for updating environmental knowledge as it fades from shared memory or in light of climate change. The motivation for such sea crossings, however, might have been to meet social and cosmological obligations implanted by the stories, singing and ritual performed at night around the fireplaces of Rubha Port an t-Seilich, Criet Dubh, and Storakaig. One can but wonder whether the much later prevalence of small isolated islands to be used as locations for spiritual devotion has its roots in the Mesolithic.

\section{SUMMARY}

We need to develop a holistic perspective on the past lives of Mesolithic hunter-gatherers. The weight of evidence from the ethnographic record suggests that early Holocene landscapes would have been enculturated with multiple levels and types of meanings. Although the content of those meanings are forever lost to us, we must nevertheless consider what role such meanings and the process of enculturation played in Mesolithic lifeways, and how these influenced the character of the archaeological record. This is the Mesolithic archaeologist's dilemma: in light of the universal presence but extraordinary diversity of meanings attached to landscapes by ethnographically documented hunter-gatherers, the risk of ignoring the existence of such meanings in the Mesolithic is as great as the risk of proposing either their content or the process by which they the landscape was enculturated. Willing to take the latter of those risks, my argument has been that we find evidence for the creation, reproduction, and revision of meanings attached to early Holocene landscapes in the most ubiquitous of evidence: the fireplaces of the Mesolithic and the burnt artefacts, bones, and charred plant material that are pervasive on Mesolithic sites.

Acknowledgements: I am grateful to Elaine Jamieson for the preparation of Figs 1 and 5, and support in the development of this manuscript, and to Mike Donnelly, Clive Waddington, and Penny Spikins for providing Figs 2, 3, $\&$ 5. Martin Bell kind providing comments and advice regarding an earlier version of this manuscript.

\section{BIBLIOGRAPHY}

Barton, R.N.E., Berridge, P.J., Walker, M.J.C. \& Bevins, R.E. 1995. Persistent places in the Mesolithic landscape: an example from the Black Mountain uplands of south Wales. Proceedings of the Prehistoric Society 61, 81-116

Basso, K.H. 1996. Wisdom Sites in Places: Landscape and language among the Western Apache. Albuquerque: University of New Mexico Press

Bell, M. 2007. Prehistoric Coastal Communities: The Mesolithic in western Britain. York: Council for British Archaeology Research Report 119

Berg-Hansen, I, Wicks, K. \& Mithen, S.J. 2019. A tanged point and two blade technologies from Rubha Port an t-Seilich, Isle of Islay, Western Scotland. Journal of Lithic Studies. DOI: https://doi.org/10.2218/jls.2892

Bird-David, N. 1990. The giving environment: Another perspective on the economic system of gatherer-hunters. Current Anthropology 31(2),189-96

Bishop, R.R., Church, M.J. \& Rowley-Conwy, P.A. 2015. Firewood, food and human niche construction: the potential role of Mesolithic hunter-gatherers in actively structuring Scotland's woodlands. Quaternary Science Reviews 108, 51-75

Bradley, R., 1984. The Social Foundations of Prehistoric Britain. London: Longman

Bradley, R. 2000. An Archaeology of Natural Places. London: Routledge

Bradshaw, R., Tolonen, K. \& Tolonen, M. 1997. Holocene records of fire from the boreal and temperate zones of Europe. In J. Clark, H. Cachier, J. Goldammer \& B. Stocks (eds), Sediment Records of Biomass Burning and Global Change, 347-65. Berlin: Springer

Caldwell, D. 2008. Islay: The Land of the Lordship. Edinburgh: Birlinn Books

Chatterton, R. 2006. Ritual. In C. Conneller \& G. Warren (eds), Mesolithic Britain and Ireland: New approaches, 101-20. Stroud: Tempus

Chatterton, R. 2007. South haw, northern England. An upland Mesolithic site in context. In C. Waddington \& K. Pedersen (eds) 2007, 69-80

Clark, J.G.D \& Rankine, W.F. 1937-8. Excavations at Farnham, Surrey (1937-38). Proceedings of the Prehistoric Society 5, 61-118

Coles, J. 1971. The early settlement of Scotland: Excavations at Morton, Fife. Proceedings of the Prehistoric Society 37, 284-366 


\section{S. Mithen. MESOLITHIC FIREPLACES \& ENCULTURATION, EARLY HOLOCENE, BRITAIN}

Conneller, C. 2004. Becoming deer: corporeal transformation at Star Carr. Archaeological Dialogues 11, 37-56

Conneller, C. 2005. Moving between sites: Mesolithic technology in the landscape. In N. Milner \& P. Woodman (eds), Mesolithic Studies at the Beginning of the 21st Century, 42-55. Oxford: Oxbow Books

Cummings,V. 2000. Myth, memory and metaphor: the significance of place, space and the landscape in Mesolithic Pembrokeshire. In R. Young (ed.), Mesolithic Lifeways: Current research from Britain and Ireland, 87-95. Leicester: Leicester University Press

Cummings, V. 2003. The origins of monumentality? Mesolithic world-views of the landscape in western Britain. In L. Larsson, H. Kindgren, K. Knutsson, D. Loeffler \& A. Akerlund (eds), Mesolithic on the Move, 74-81. Oxford: Oxbow Books

David, A. 2007. Palaeolithic and Mesolithic Settlement in Wales, with special reference to Dyfed. Oxford: British Archaeological Report 448

Davies, P., Robb, J.G. \& Ladbrook, D. 2005. Woodland clearance in the Mesolithic: the social aspects. Antiquity 79, 280-8

Edmonds, M.R. 1997. Taskscape, technology and tradition. Analecta Praehistorica Leidensia 29, 99-110

Edwards, K.J. 1990. Fire and the Scottish mesolithic: evidence from microscopic charcoal. In P.M. Vermeesch \& P. Van Peer (eds), Contributions to the Mesolithic in Europe, 71-9. Leuven: Leuven University Press

Edwards, K.J. 2000. Vegetation history of the southern Inner Hebrides during the Mesolithic period. In Mithen (ed.) 2000, 115-27

Edwards, K., Langdon, P. \& Sugden, H. 2007. Separating climatic and possible human impacts in the early Holocene: biotic response around the time of the 8200 cal. yr BP event. Journal of Quaternary Science 22(1), 77-84

Ellis, C.J., Allen, M.J., Gardiner, J., Harding, P., Ingrem, C., Powell, A. \& Scaife, R.G. 2003. An early Mesolithic seasonal hunting site in the Kennet Valley, southern England. Proceedings of the Prehistoric Society 69, 107-35

Ferguson, K. \& Perrons, M. 1988. Place Names of Islay. Port Charlotte: Museum of Islay Life

Froom, R. 2012. The Mesolithic of the Kennet Valley. Newbury: Roy Froom publication

Funk, C. 2011. Yupik Eskimo gendered information storage patterns. In R. Whallon, W. Lovis \& R. Hitchcock (eds), The Role of Information in Hunter-Gatherer Bands, 29-58. Los Angeles: Cotsen Institure of Archaeology, University of California

Gardiner, P. 2007. Mesolithic activity at Hawkcombe Head, Somerset: an interim report on the 2002-3 excavations. In Waddington \& Pedersen (eds) 2007, 81-95

Gooder, J. 2007. Excavation of a Mesolithic house at East Barns, East Lothian, Scotland: an interim review. In Waddington \& Pedersen (eds) 2007, 49-60

Jarvenpa, R. \& Brumbach, H.J. 2016. Initializing the landscape. Chipewyan construction of meaning in a recently occupied landscape. In Lovis \& Whallon (eds) 2016, $18-41$
Jones, R. 2012. Fire-stick farming. Fire Ecology 8, 3-18 (originally published 1969 in Australian Natural History 16, 224-231)

Jordan, P. 2003. Material Culture and Sacred Landscape: The anthropology of the Siberian Khanty. Walnut Creek, CA: AltaMira Press

Jordan, P. 2010 (ed.). Landscape and Culture in Northern Eurasia. London: Taylor \& Francis

Lavrillier, A. 2010. The creation and persistence of cultural landscapes among the Siberian Evenkis: Two conceptions of sacred space. Jordan (ed.) 2010, 215-31

Lejay, M., Alexis, M., Quénéa, K, Sellami, F. \& Bon, F. 2016. Organic signatures of fireplaces: experimental references for archaeological interpretations. Organic Geochemistry 99, 67-77

Lewis, J.S.C. \& Rackham, J. 2011. Three Ways Wharf, Uxbridge. A Late Glacial and Early Holocene Huntergatherer site in the Colne Valley. London: Museum of London Archaeology

Lillie, M. 2015. Hunters, Fishers \& Foragers in Wales. Towards a social Narrative of Mesolithic lifeways. Oxford: Oxbow Books

Lovis, W.A. 2016. Network maintenance in big rough spaces with few people. In Lovis \& Whallon (eds) 2016, 59-69

Lovis, W.A. \& Whallon, W. 2016. Marking the Land. Hunter-Gatherer Creation of Meaning in their Environment. Abingdon: Routledge

Lynn, C. 2014. Hearth and campfire influences on arterial blood pressure: defraying the costs of the social brain through fireside relaxation. Evolutionary Psychology 12(5), 983-1003

Manzi, L.M. \& Spikins, P. 2008. El fuego en las atlas latitudes: Los Selk'nam de Tierra del Fuego como referente etnográfico para el Mesolítico europea. Complutum 19, 97-6.

Marshall, L. 1976. The !Kung of Nyae Nyae. Cambridge MA: Harvard University Press.

Mason, S.L.R. 2000. Fire and Mesolithic subsistence - managing oaks for acorns in northwest Europe? Palaeogeography, Palaeoclimatology, Palaeoecology 164, 139-50

McCullagh, R. 1989. Excavation at Newton, Islay. Scottish Archaeological Journal 15, 23-51

McFadyen, L. 2006. Landscape. In C. Conneller \& G. Warren (eds), Mesolithic Britain and Ireland: New approaches, 121-38. Stroud: Tempus

McInnes, E. 2016. Both artefact and phenomenon: a material approach to engagements with fire in the Late Mesolithic of Britain. In J. Debert, M. Larsson \& J. Thomas (eds), In Dialogue: Tradition and interaction in the Mesolithic-Neolithic transition, 47-54. Oxford: British Archaeological Report S2809

Meggitt, M. 1986 [1962]. Desert People: A Study of the Walbiri Aborigines of Central Australia. Sydney: Angus \& Robertson

Mellars, P. 1976. Fire ecology, animal populations and man: a study of some ecological relationships in prehistory. Proceedings of the Prehistoric Society 42, 15-45. 
Mellars, P. 1987. Excavations on Oronsay: Prehistoric human ecology on a small island. Edinburgh: Edinburgh University Press

Mellars, P. \& Dark, P. 1998. Star Carr in Context. Cambridge: McDonald Institute for Archaeological Research

Mercer, J. 1974. Glenbatrick Waterhole, a microlithic site on the Isle of Jura. Proceedings of the Society of Antiquaries of Scotland 105, 9-32

Mercer, J. 1978. Lussa Wood 1: The Late-Glacial and Early PostGlacial Occupation of Jura. Proceedings of the Society of Antiquaries of Scotland 110, 1-32

Milner, N. 2009. Mesolithic consumption practices: food for thought. Journal of Nordic Archaeological Science 16, 49-64

Milner, N., Conneller, C. \& Taylor, B. (eds), 2018. Star Carr Volume 1: A Persistent Place in a Changing World. York: White Rose University Press. DOI: https://doi.org/10. 22599/book1

Minc, L. 1986. Scarcity and survival: The role of oral tradition in mediating subsistence crises. Journal of Anthropological Archaeology 5, 39-113

Mithen, S.J. 1996. The Prehistory of the Mind. London: Thames \& Hudson

Mithen, S.J. 2000. Hunter-gatherer Landscape Archaeology: The Southern Hebrides Mesolithic Project. Cambridge: Macdonald Institute for Archaeological Research

Mithen, S.J. \& Finlay, N. 2000. Coulererach, Islay: Testpit survey and trial excavation. In Mithen (ed.) 2000, 217-30

Mithen, S.J., Lake, M. \& Finlay, N. 2000a. Bolsay Farm, Islay: Area excavation. In Mithen (ed.) 2000, 291-330

Mithen, S.J., Woodman, P.E., Finlay, N. \& Finlayson, B. 2000b. Aoradh: Test-pit survey and trial excavation. In Mithen (ed.) 2000, 231-40

Mithen, S.J., Finlay, N., Carruthers, W., Carter, P. \& Ashmore, P. 2001. Plant use in the Mesolithic: The case of Staosnaig. Journal of Archaeological Science 28, 223-34

Mithen, S.J. \& Wicks, K. 2018. The interpretation of Mesolithic structures in Britain: New evidence from Criet Dubh, Isle of Mull, and alternative approaches to chronological analysis for inferring occupation tempos and settlement patterns. Proceedings of the Prehistoric Society 84, 77-110

Mithen, S.J., Wicks, K. \& Berg-Hansen, I. in press. The Mesolithic coastal exploitation of western Scotland: the impacts of climate change and use of favoured locations. In A. Schülke (ed), The Coastal Landscapes of the Mesolithic. London: Routledge

Mithen, S.J., Wicks, K, Pirie, A.E., Riede, F., Lane, C., Banjerea, R., Cullen, V., Gittins, M. \& Pankhurst, N. 2015. A late glacial archaeological site and tephra sequence in the far northwest of Europe: Ahrensburgian artefacts and geoarchaeology at Rupha Port an t-Seilich, Isle of Islay, western Scotland. Journal of Quaternary Science 30, 396-416

Moore, J. 2003. Enculturation through fire: beyond hazelnuts and into the forest. In L. Larsson,
H. Kindgren, K. Knutsson, D. Loeffler \& A. Åkerlund (eds), Mesolithic on the Move, 139-44. Oxford: Oxbow Books

Oetelaar, G. 2016. Places on Blackfoot homeland: Markers of cosmology, social relationship and history. In Lovis \& Whallon (eds) 2016, 42-57

Palmer, S. 1999. Culverwell Mesolithic Habitation Site. Oxford: British Archaeological Report 287

Peters, H. \& Niekus, M.J.L.T. 2017. Mesolithic pit hearths in the northern Netherlands. Function, time-depth and behavioural context. In N. Achard-Corompt, E. Ghesquière \& V. Riquier (eds), Creuser au Mésolithique Digging in the Mesolithic, 225-41. Paris: Société Préhistorique Française

Pollard, J. 2000. Ancestral places in the Mesolithic landscape. Archaeological Review from Cambridge 17, 123-38

Radley, J. \& Mellars, P. 1964. A Mesolithic structure at Deepcar, Yorkshire, England and the affinities of its associated flint industries. Proceedings of the Prehistoric Society 30, 1-24

Radley, J., Tallis, J.H. \& Switsur, V.R. 1974. The excavation of three 'narrow blade' Mesolithic sites in the southern Pennines, England. Proceedings of the Prehistoric Society 40, 1-19

Rankine, W.F. 1952. A Mesolithic chipping floor at The Warren, Oakhanger, Selborne, Hants. Proceedings of the Prehistoric Society 18, 21-35

Robertson, A., Lochrie, J. \& Timpany, S. 2013. Built to last: Mesolithic and Neolithic settlement at two sites beside the Forth estuary, Scotland. Proceedings of the Society of Antiquaries of Scotland 143, 1-64

Royal Commission on the Ancient and Historical Monuments of Scotland (RCAHMS) 1985. Argyll: An inventory of the monuments vol. 5: Islay, Jura, Colonsay and Oronsay. London: Her Majesty's Stationary Office

Rockman, M, \& Steele, J. (eds). 2003. Colonization of Unfamiliar Landscapes. The archaeology of adaptation. London: Routledge

Score, D. \& Mithen, S.J. 2000. The experimental roasting of hazelnuts. In Mithen (ed.) 2000, 507-12. Cambridge: McDonald Institute for Archaeological Research

Sergant, J., Crombe, P. \& Perdaen, Y. 2006. The 'invisible' hearths: a contribution to the discernment of Mesolithic non-structured surface hearths. Journal of Archaeological Science 33, 999-1007

Sikk, K. 2016. Quantifying the use of stones in the Stone Age fireplaces of Estonia. DOI: http://dx.doi.org/10.15388/ ArchLit.2016.17.10680

Simmons, I.G. 1996. The Environmental Impact of Later Mesolithic Cultures. Edinburgh: Edinburgh University Press

Smith, D., Schlaepfer, P., Major, K., Dyble, M., Page, A.E., Thompson, J., Chaudhary, N., Salali, G.D., Mace, R. Astete, L. Ngales, M., Vinicius, L. \& Migliano, A.B. 2017. Cooperation and the evolution of hunter-gatherer storytelling. Nature Communications 8, 1853. DOI: 10. 1038/s41467-017-02036-8 


\section{S. Mithen. MESOLITHIC FIREPLACES \& ENCULTURATION, EARLY HOLOCENE, BRITAIN}

Spikins, P. 2000. Prehistoric People of the Pennines: Reconstructing the lifestyles of Mesolithic buntergatherers on Marsden Moor. Wakefield: West Yorkshire Archaeology Service

Spikins, P., Kelly, R. \& Manzi, L. 2010. 'When the last fires were put out': ethnographic analogy and the symbolic use of fire in the Palaeolithic and Mesolithic. Quaderni di Thule, XXXII Convegno Internazionale di Americanistica, 183-92. Perugia: no publisher given

Takada, A. 2016. Unfolding cultural meanings: Wayfinding practices among the San of the Central Kalahari. In Lovis \& Whallon (eds) 2016, 92-106

Taylor, B. 2018. Subsistence, environment and Mesolithic landscape archaeology. Cambridge Archaeological Journal 28, 493-510

Taylor, B., Conneller, C., Milner, N., Elliott, B., Little, A., Knight, B. \& Bamforth, M. 2018. Human Lifeways. In N. Milner, C. Conneller \& B. Taylor (eds), Star Carr Volume 1: A persistent place in a changing world, 45-272. York: White Rose University Press. DOI: https://doi.org/10.22599/book1.j

Tilley, C. 1994. A Phenomenology of Landscape. Places, Paths and Monuments. Oxford: Berg

Tipping, R. 1996. Microscopic charcoal records, inferred human activity and climate change in the Mesolithic of northernmost Scotland. In A. Pollard \& A. Morrison (eds), The Early Prehistory of Scotland, 39-61. Edinburgh: Edinburgh University Press

Tipping, R. 2008. Storminess as an explanation for the decline of pine woodland ca. 7,400 years ago at Loch Tulla, western Scotland. Vegetation History \& Archaeobotany 17, 345-50

Vaté, V. 2010. Dwelling in the landscape among the reindeer herding Chukchis of Chukota. In Jordan (ed.) 2010, 13560. London: Taylor \& Francis

Waddington, C. 2007a. Mesolithic Settlement in the North Sea Basin. A Case Study from Howick, North-East England. Oxford: Oxbow Books

Waddington, C. 2007b. Rethinking Mesolithic settlement and a case study for Howick. In Waddington \& Pedersen (eds) 2007, 101-13

Waddington, C. 2015. Mesolithic re-colonisation of Britain following the drowning of North Sea landscapes. In N. Ashton \& C. Harris (eds), No Stone Unturned: Papers in honour of Roger Jacobi, 221-32. London: Lithic Studies Society

Waddington, C. \& Bonsall, C. 2016. Archaeology and Environment on the North Sea Littoral: A case study from Low Hauxley. Bakewell: Archaeological Research Services

Waddington, C \& Pedersen K.L.R. (eds). 2007. Mesolithic Studies in the North Sea Basin and Beyond. Oxford: Oxbow Books

Waddington, C., Bailey, G., Bayliss, A. \& Milner, N. 2007. Howick in its North Sea context. In Waddington (ed.) 2007a, 203-24

Warren, G. 2005. Mesolithic Lives in Scotland. Stroud: Tempus
Warren, G., Fraser, S., Clarke, A., Driscoll, K., Mitchell, W., Noble, G., Paterson, D., Schulting, R., Tipping, R., Verbaas, A, Wilson, C. \& Wickham-Jones, C. 2017. Little house in the mountains? A small Mesolithic structure from the Cairngorm Mountains, Scotland. Journal of Archaeological Science: Reports 18, 936-45

Whallon, R. \& Lovis, W.A. 2016. Hunter-gatherer landscape perception and landscape 'marking'. In Lovis Whallon (eds) 2016, 10-17

Woodman, P. 1987. Excavations at Cass Ny Hawin, Isle of Man. Proceedings of the Prehistoric Society 53, 1-22

Wiessner, P.W. 2014. Embers of society: Firelight talk among the Ju/'hoansi Bushmen. Proceedings of the National Academy of Sciences 111, 14027-35

Wickham-Jones, C.R. 1990. Rhum: Mesolithic and later sites at Kinloch, Excavations 1984-86. Edinburgh: Society of Antiquaries of Scotland, Monograph 7

Wickham-Jones, C.R. \& Dalland, M. 1998. A small Mesolithic site at Fife Ness, Fife, Scotland. Internet Archaeology 5. https://doi.org/10.11141/ia.5.1

Wicks, K. \& Mithen, S.J. 2014. The impact of the abrupt 8.2 $\mathrm{Ka}$ cold event on the Mesolithic population of western Scotland: A Bayesian chronological model using 'activity events' as a population proxy. Journal of Archaeological Science 45, 240-69

Wicks, K. \& Mithen, S.J. 2017. Economy and environment during the early Mesolithic of western Scotland: Repeated visits to a fishing locality on a small island in the Inner Hebrides. In P. Persson, E. Reide, B. Skar, H.M. Breivik \& L. Johnson (eds), The Ecology of Early Settlement in Northern Europe: Conditions for subsistence and survival, 20-55. Sheffield: Equinox

Wicks, K., Pirie, A.E. \& Mithen, S.J. 2014. Settlement patterns in the Late Mesolithic of western Scotland: The implications of Bayesian analysis of radiocarbon dates and inter-site technological comparisons. Journal of Archaeological Science 41, 406-22

Willerslev, R. 2010. Seeing with others' eyes: hunting and 'idle talk' in the landscape of the Siberian Iukagir. In Jordan (ed.) 2010, 49-70

Woodman, P. 1985. Excavations at Mount Sandel 1973-77. Belfast: Her Majesty's Stationary Office

Wymer, J. 1959. Excavations at the Mesolithic site at Thatcham, Berks - 1958. Berkshire Archaeological Journal 57, 1-24

Wymer, J. 1962. Excavations at the Maglemosian sites at Thatcham, Berkshire, England. Proceedings of the Prehistoric Society 28, 329-99

Youngson, P. 2001. Jura. Island of Deer. Edinburgh: Birlinn

Zvelebil, M., 1994. Plant use in the Mesolithic and its role in the transition to farming. Proceedings of the Prehistoric Society 60, 35-74

Zvelebil, M. 2003. Enculturation of Mesolithic landscapes. In L. Larsson, H. Kindgren, K. Knutsson, D. Loeffler \& A. Åkerlund (eds), Mesolithic on the Move, 65-73. Oxford: Oxbow Books 


\section{RÉSUMÉ}

Foyers mésolithiques et l'acculturation des paysages du début de l'Holocène en Grande-Bretagne, avec une étude de cas de l'Ecosse de l'ouest, de Steven Mithen

A la lumière de l'acculturation des paysages par des chasseurs cueilleurs ethnographiquement documentés, nous devrions nous attendre à ce que ces chasseurs cueilleurs mésolithiques aient doté leurs paysages du début de l'Holocène de signification. Des tentatives pour en trouver les témoignages se sont concentrées sur l'inhabituel et l'exotique, ces aspects des rapports archéologiques qui semblent immédiatement n'avoir aucun lien avec la subsistance. Dans cette contribution, je suggère que les foyers, omniprésents sur les sites mésolithiques et souvent passés rapidement sous silence dans les rapports de sites comme témoignage de cuisine uniquement, avaient joué un rôle clé dans le procédé d'acculturation du paysage. Bien que nous ne puissions reconstruire les significations spécifiques liées aux paysages du début de l'Holocène à un moment donné,par notre appréciation de la signification sociale et culturelle des foyers, nous parvenons à une vision plus holistique du Mésolithique que ce n'est le cas actuellement,que ce soit dans ces études qui se concentrent sur l'occupation et la subsistance ou dans celles qui citent des exemples de rituels. Au cours de l'élaboration de cette dicussion, je résume les témoignages de foyers de la Grande-Bretagne mésolithique, notant le besoin de comptes rendus plus systématiques. Finalement, j'apporte une étude de cas de l'Ecosse de l'ouest qui tente de visionner une suite de foyers dans le contexte la topographie du paysage, de l'environnement du début de l'Holocène,de l'économie de subsistance et en faisant appel à des analogies ethnographiques sélectionnées

\section{ZUSSAMENFASSUNG}

Mesolithische Feuerstellen und die Enkulturation von Landschaften des frühen Holozäns in Großbritannien, mit einer Fallstudie aus Westschottland, von Steven Mithen

Im Licht der Enkulturation von Landschaften durch ethnographisch dokumentierte Jäger-Sammler sollten wir bei mesolithischen Jäger-Sammlern davon ausgehen, dass sie ihre Landschaften des frühen Holozäns mit Bedeutung versehen haben. Bisherige Versuche Hinweise hierauf $\mathrm{zu}$ finden konzentrierten sich auf das Ungewöhnliche und Exotische - jene Aspekte der archäologischen Überlieferung, die nicht unmittelbar mit der Subsistenz verbunden zu sein scheinen. In diesem Beitrag erörtere ich, dass Feuerstellen, die auf mesolithischen Fundplätzen allgegenwärtig sind und in Grabungsberichten oft flüchtig allein als Hinweis auf das Kochen angesprochen werden, eine zentrale Rolle in dem Prozess der Enkulturation von Landschaft inne hatten. Auch wenn wir die spezifischen Bedeutungen nicht rekonstruieren können, die einst den frühen holozänen Landschaften beigemessen wurden, können wir durch die Würdigung der sozialen und kulturellen Signifikanz von Feuerstellen eine holistischere Sicht des Mesolithikums als bisher gewinnen, sei es in Untersuchungen, die auf Siedlungsweise und Subsistenz fokussieren, oder solchen, die Beispiele für rituelles Handeln aufrufen. In dieser Erörterung fasse ich Hinweise für Feuerstellen aus dem mesolithischen Großbritannien zusammen und verweise auf die Notwendigkeit einer systematischeren Dokumentation. Schließlich lege ich eine Fallstudie aus dem westlichen Schottland vor, die eine Reihe von Feuerstellen im Kontext der Landschaftstopographie, der frühholozänen Umwelt und der Subsistenzwirtschaft betrachtet und ausgewählte ethnographische Analogien zum Vergleich heranzieht.

\section{RESUMEN}

Los hogares mesolíticos y la enculturación de los paisajes del Holoceno inicial en Gran Bretaña, con un estudio de caso del oeste de Escocia, por Steven Mithen.

A la luz de la enculturación de los paisajes por parte de cazadores-recolectores documentados etnográficamente, cabría esperar que los cazadores-recolectores mesolíticos hayan dotado de significado a sus primeros paisajes en el Holoceno inicial. Los intentos por encontrar evidencia de este aspecto se han centrado en lo inusual y lo exótico - aquéllos aspectos del registro arqueológico que parecen no tener relación alguna con la subsistencia. En esta contribución, sugiero que los hogares, abundantes en los yacimientos mesolíticos y a menudo no 


\section{S. Mithen. MeSOLITHIC FIREPLACES \& ENCULTURATION, EARLy HOLOCENE, BRITAIN}

considerados en los informes por relacionarse exclusivamente con las actividades culinarias, han jugado un papel fundamental en el proceso de enculturación de los paisajes. Aunque no podemos reconstruir los significados específicos a los que estaban vinculados en los paisajes del Holoceno inicial, al revalorizarse la significación social y cultural de estos hogares, adoptamos una visión más holística del Mesolítico de lo que es actualmente, ya sea en aquéllos estudios que se centran en el asentamiento y la subsistencia o en aquéllos que citan ejemplos rituales. En el transcurso de esta argumentación, resumo la evidencia que existe sobre hogares en el Mesolítico en Gran Bretaña, resaltando la necesidad de una información más sistemática. Finalmente, aporto un estudio de caso del oeste de Escocia que busca observar en un conjunto de hogares en el contexto de la topografía del paisaje, los ambientes del Holoceno inicial y la economía de subsistencia, recurriendo a una serie de analogías etnográficas seleccionadas. 